\title{
Permo-Triassic sedimentary fills and tectonic phases off Mid Norway: seismic investigation of the Trøndelag Platform
}

\section{Keywords:}

- Sedimentary fill

- sedimentary wedge

- Trøndelag Platform

- Helgeland Basin

- Froan Basin

- Nordland Ridge

- Tectonic phase

- Norwegian-Greenland seaway

Received:

Accepted:

22. April 2020

Published online:

8. July 2020
13. December 2019

\author{
Emily Barnabas Kiswaka ${ }^{1} \&$ Maarten Felix ${ }^{1}$ \\ ${ }^{1}$ NTNU Norwegian University of Science and Technology, N-7491, Trondheim, Norway \\ E-mail corresponding author (Emily Kiswaka):emily.kiswaka@ntnu.no
}

Seismic interpretation (2D and new 3D surveys) has been used to investigate sedimentary fills and timing of tectonic activity offshore Mid Norway. This study was focused on upper Permian and Lower Triassic sedimentary basin fills, but a longer stratigraphic interval (Devonian-Upper Triassic) was analysed in order to get a broad understanding of what happened prior to, during and after deposition of the upper Permian-Lower Triassic successions. The ages of the sedimentary fills were partly constrained by well ties. Seismic reflectors and sedimentary successions below the upper Permian interval are of Late Devonianmid Permian age. Six sedimentary fill geometries (fill type A - F) were identified. These are (A) fault-ward thickening packages with internal strata thickening towards bounding faults, (B) wedge-shaped packages whose internal strata have more or less uniform thickness, (C) sedimentary fills containing fill type A overlain by sedimentary strata with more or less uniform thickness, (D) gently dipping packages that thicken towards deeper areas of the basin, and downlap onto pre-existing topography, (E) gently dipping strata filling depressions, and (F) sedimentary wedge with rotated internal strata and folded top. These fill types were used to determine phases of active tectonics and quiescent phases. Based on temporal changes of the fill types, five late Palaeozoic-Triassic unconformities have been mapped: a nonconformity where the Palaeozoic strata onlap onto the basement, a mid-Permian unconformity, two Early Triassic unconformities and a Middle Triassic angular unconformity. Results show that Devonian- Permian, mid-Permian, latePermian, Early Triassic, late Early Triassic, and Mid-Late Triassic rifts influenced

\section{Introduction}

The Norwegian-Greenland seaway opened as the result of multiple tectonic episodes that started in the Carboniferous (Brekke, 2000) and ended with the final separation during the late Palaeocene (Surlyk, 1990). Three main rifting episodes related to the opening have been recognised regionally; these are events during the late Carboniferous to early Permian (Blystad et al., 1995), middle Permian (Surlyk et al., 1984; Surlyk, 1990; Doré, 1992; Seidler, 2000; Oftedal et al., 2005; Guarnieri et al., 2017) and Early Triassic (Seidler et al., 2004; Müller et al., 2005). The late-Palaeozoic tectonics created the framework for the tectono-sedimentary

(c) Copyright the authors. This work is licensed under a Creative Commons Attribution 4.0 International License.
Kiswaka, E.B. \& Felix, M. 2020: Permo-Triassic sedimentary fills and tectonic phases off Mid Norway: seismic investigation of the Trøndelag Platform. Norwegian Journal of Geology 100, 202009. https://dx.doi.org/10.17850/njg100-2-3. 
development of the Norwegian Sea basin (Brekke, 2000). Minor block movements in the late Permian are considered to mark initial stages of the Early Triassic rifting that created several sub-basins which were controlled by major faults (Müller et al., 2005; Redfern et al., 2010). Müller et al. (2005) reported that a short-lived marine incursion occurred during the Middle Triassic, suggesting local tectonics or eustatic sea-level rise during that time period.

Not all tectonic pulses affected the entire area though, and several pulses have been recognised only in individual basins, indicating different developments in different basins (Müller et al., 2005). These local tectonic pulses occurred outside the major phases mentioned above. For example, two Early Triassic marine rifting events are recorded from eastern Greenland outcrops (Seidler et al., 2004; Guarnieri et al., 2017), but offshore Mid Norway only one Early Triassic tectonic event has been reported based on Lower Triassic basin infill geometries (Müller et al., 2005). The local tectonic developments are not as well known as the regional development and have sometimes only been suggested in the literature (e.g., Müller et al., 2005) rather than described in detail.

The upper Palaeozoic and Lower Triassic deposits of eastern Greenland have been widely studied (Surlyk et al., 1984; Surlyk et al., 1986; Christiansen et al., 1993; Stemmerik et al., 1993; Kreiner-Møller \& Stemmerik, 2001), made possible because they are exposed onshore. Less work has been done on the PermoTriassic successions of the Norwegian Sea basin that are deeply buried in the Trøndelag Platform (Fig. 1). Earlier work on the Permo-Triassic deposits of the Norwegian Sea area has focused on cores (especially 6609/7-1, 6611/09-U-01 6611/09-U-02 and 6608/8-1), interpretation of 2D seismic data (most of which have limited quality) and correlation with eastern Greenland (Blystad et al., 1995; Brekke, 2000; Bugge et al., 2002; Müller et al., 2005).

In the current study, seismic investigation of the Trøndelag Platform including its subsidiary elements the Frøya High, Nordland Ridge, Helgeland Basin and Froan Basin (Fig. 1), and similarities with eastern Greenland geology, have been used to study sedimentary fill geometries and faults to improve our understanding of the tectono-sedimentary development of the deeper parts of the study area, and determine the effects of both regional and local tectonic phases, which have until now been unclear. This work was aimed at studying the upper Permian and Lower Triassic successions, but older and younger intervals were also studied for a fuller understanding of the basin development. New 3D surveys were used that were unavailable for previous work, which allowed looking into the deeper parts of the basin and improved the confidence in recognition of the structures present.

\section{Stratigraphy of the study area}

A formal stratigraphic subdivision of the rocks in the area does not exist, but Bugge et al. (2002) and Müller et al. (2005) have subdivided the deposits into multiple units (see Fig. 2). Description of cores 6611/09-U-01 and 6611/09-U-02 allowed Bugge et al. (2002) to report four Permo-Triassic lithological units on the eastern margin of the Helgeland Basin. These are, from oldest to youngest: Shallow-Marine Sandstone Unit, Anhydrite Unit, Lower Turbidite Unit, and Upper Turbidite Unit (Fig. 2). These units were correlated with formations encountered in eastern Greenland (Fig. 2). The Shallow-Marine Sandstone Unit marks the base of the Permo-Triassic stratigraphy in core 6611/09-U-01 and rests most likely on crystalline basement (Bugge et al., 2002). The Anhydrite Unit follows upward and contains abundant gypsum-filled fractures and anhydrite nodules (Bugge et al., 2002). The Lower Turbidite Unit is overlain by the Upper Turbidite Unit, and their common boundary was placed at the Permian-Triassic boundary. A possible hiatus exists between the upper Permian and the Lower Triassic (Bugge et al., 20002; Müller et al., 2005). This unconformity may be regional as the Permo-Triassic boundary in eastern Greenland has been described as unconformable in places (e.g., Stemmerik et al., 1997; Guarnieri et al., 2017). 


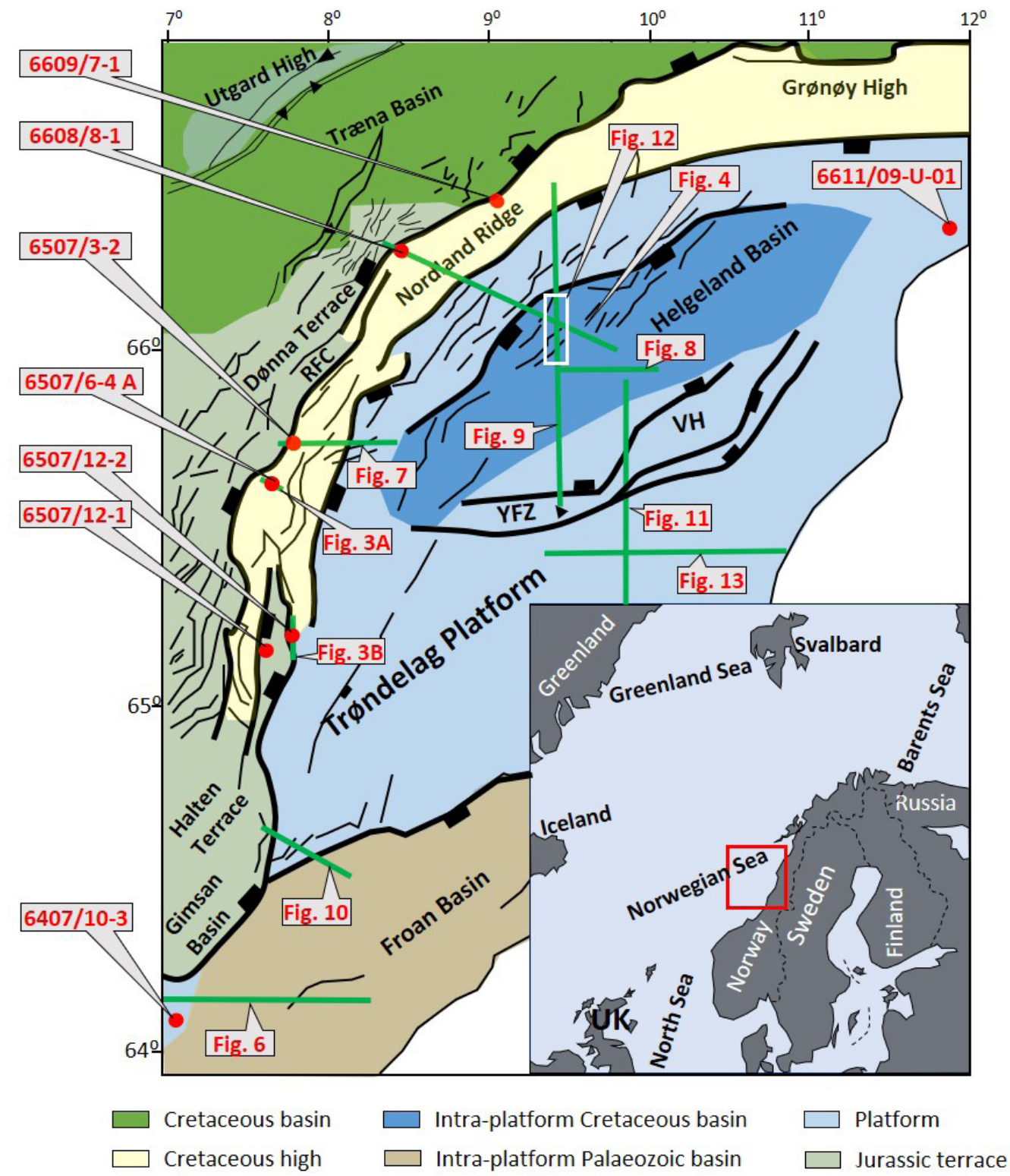

Figure 1. Structural element map of the Trøndelag Platform area with the locations of key cores and seismic lines used to illustrate the findings. Major extensive faults are shown by thick black lines while small faults are shown by the thin black lines. Main map sourced from NPD FactMaps (http://npdwms.npd.no/npdwmsmap_wgs84.asp?; March 13, 2018). Inset map modified after Bugge et al. (2002). Structural elements modified from Blystad et al. (1995). RFC Revfallet Fault Complex, VH - Vega High and YFZ - Ylvingen Fault Zone.

The Early Triassic, offshore Mid Norway, began by deposition of the Upper Turbidite Unit, which is correlated with the Wordie Creek Formation of eastern Greenland (Bugge et al., 2002). The sediments in eastern Greenland also consist of deep-water, gravity-flow deposits, and the sequence there contains erosional surfaces associated with an Early Triassic rifting event (e.g., Surlyk et al., 1986; Seidler, 2000; Seidler et al., 2004).

Müller et al. (2005) subdivided the Triassic stratigraphy offshore Mid Norway into five sedimentological units based on seismic interpretation and core logging. These authors named the units $\operatorname{Tr} 1$ to $\operatorname{Tr} 5$, and described them as follows. Unit Tr1 is dominated by submarine-fan deposits and minor marginal marine deposits. This depositional unit is the same as the Upper Turbidite Unit of Bugge et al. (2002). Unit Tr2 is dominated by marginal marine deposits. Unit Tr3 is continental, as implied by its brownish-red colour, 


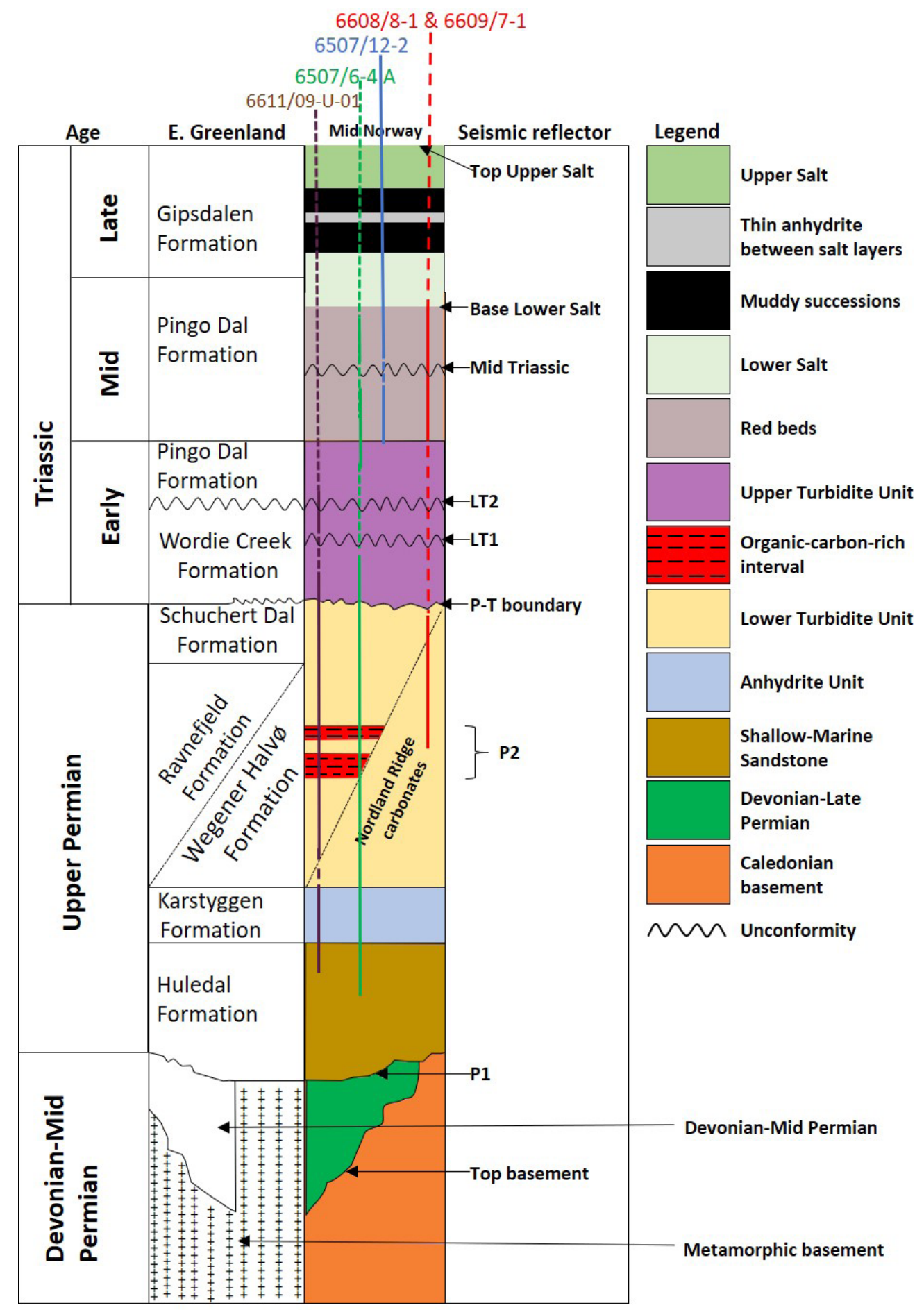

Figure 2. Correlated chronostratigraphic schemes between the Helgeland Basin and eastern Greenland with vertical positions of the major reflectors (see main text for further description). The exact position of P2 is uncertain, therefore the possible range is shown. Dashed vertical lines show intervals that were not penetrated by wellbores. Stratigraphic columns have been modified after Jacobsen \& van Veen (1984), Surlyk (1990), Stemmerik et al. (1993), Stemmerik et al. (1997), Seidler (2000), Bugge et al. (2002), Seidler et al. (2004), Müller et al. (2005), Guarnieri et al. (2017), and Andrews \& Decou (2019). P1 - mid-Permian unconformity, P2 - late-Permian reflector and LT1 and LT2 are the Lower Triassic reflectors.

and partly marginal marine as shown by the presence of scattered marine algae. Müller et al. (2005) dated this depositional unit as Mid Triassic. Unit Tr4 is dominated by marine deposition as shown by the presence of evaporites. These evaporites consist of two thick halite beds (called Lower Salt and Upper 
Salt) separated by a thick mudstone succession which contains a thin anhydrite (Jacobsen \& van Veen, 1984; Müller et al., 2005). The youngest Triassic interval was named unit Tr5 and its base is marked by an extensive mud-dominated deposit thought to have been deposited in a shallow lacustrine basin (Müller et al., 2005). The seismic boundary between unit $\operatorname{Tr} 4$ and $\operatorname{Tr} 5$ is marked by a strong amplitude reflector (top Upper Salt). The upper part of Unit Tr5 is characterised by thick sandstones, interbedded with greenish-grey mudstones and thin coal beds (Müller et al., 2005). This alternation marks the transition into the Lower Jurassic Åre Formation (Dalland et al., 1988).

\section{Dataset and methodology}

Over one hundred 2D seismic lines and two 3D seismic cubes have been used for the interpretation of the study area. Wellbores 6507/6-4 A and 6608/8-1 have penetrated the upper Permian reflectors and upper Permian sedimentary packages (Müller et al., 2005; NPD, 2013) on the margins of the Trøndelag Platform (Fig. 1). These reflectors and packages have been followed from where the seismic lines cross the wellbores to the deeper basinal areas. The specific amplitude characteristics of the reflectors were used in their identification on the different lines, ensuring a correct description especially where reflectors were difficult to follow. On these lines, nine major reflectors were interpreted to identify the stratigraphic positions of different basin fills and to study the tectonic development of the area. These reflectors are, from oldest to youngest (Fig. 2): the top of the basement, two Permian reflectors (called P1 and P2), and six Triassic reflectors. The Triassic reflectors are: a PermoTriassic (P-T) reflector (most likely the Permo-Triassic boundary, as discussed below), two Lower Triassic reflectors (LT1 and LT2), the Mid Triassic reflector, the base Lower Salt, and top Upper Salt reflectors (Fig. 2). Age assignments for the reflectors in the deeper parts of the Froan Basin are limited by the absence of well control. The ages of the P2 reflector, base Lower Salt reflector and top Upper salt reflector were established from well ties (Figs. $3 \& 4$ ). The ages of reflectors below P1 as well as the ages of P1, LT1 and LT2, are assigned tentatively, based on their seismic stratigraphic positions (above
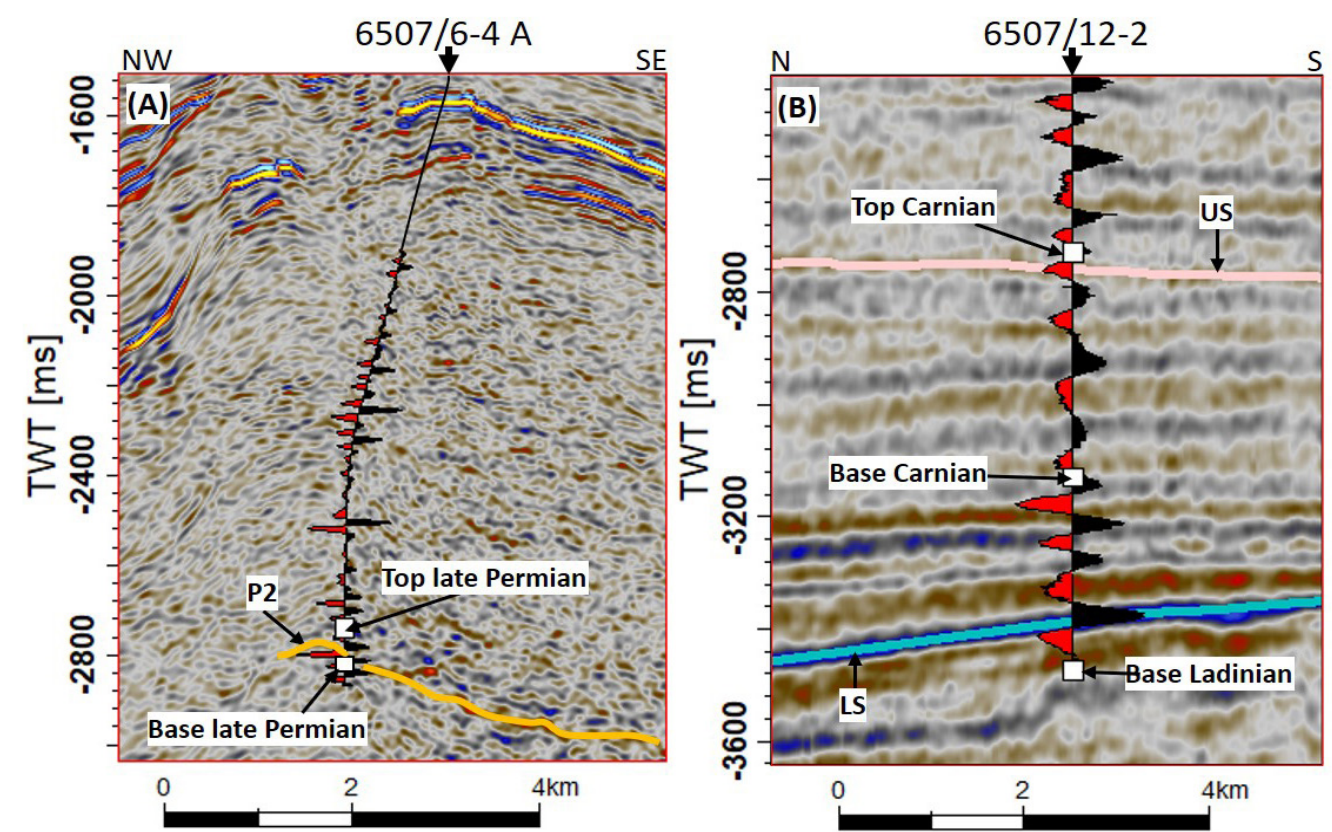

Figure 3. Well ties used to constrain ages of the analysed interval. In this figure, negative and positive seismic responses are shown by red and blue/black colours, respectively. (A) 3D inline 9240 of the ST13M09 survey constraining the P2 age on core 6507/6-4 A in the Nordland Ridge. Here, the P2 reflector was traced on a negative reflector. (B) 2D seismic line crossing well 6507/12-2 constraining the ages for the base Lower Salt (LS) and top Upper Salt (US) reflectors in the Trøndelag Platform. TWT - two-way-travel time. 
or below) relative to the P2 and base Lower Salt reflectors, and based on onlap features. The absence of good time control means that the assignments can only be tentative, and future work may result in some shifts when better time control becomes available. All deposits below the studied reflectors are assumed to be of Late Devonian to mid Permian age.

Different stratal relationships (onlap, downlap and toplap) were keys to identifying unconformities in the studied succession. The identification of the unconformities was based on definitions and findings of Mitchum et al. (1977) and Kyrkjebø et al. (2004). An unconformity was identified as an onlap or downlap surface in the interiors of the sub-basins and as an angular unconformity in the platform highs (also see Kyrkjebø et al., 2004).

The term unconformity is used here despite the lack of firm time control, meaning that the surface referred to could be an actual unconformity, a diastem, or a more complex surface. This use of terminology follows previous descriptions of the stratigraphy in the area, but may need to be changed in the future if better information becomes available. Unconformities have traditionally been considered to be timelines/barriers that separate younger deposits from older strata (Mitchum et al., 1977), but recently it has been shown that these surfaces can be composite and diachronous and do not always separate younger strata from older rocks (Kyrkjebø et al., 2004; Holbrook and Bhattacharya, 2012; Gani, 2017). A composite surface is defined by Gani (2017) as "an amalgamation of many surfaces, simultaneously representing surfaces of deposition, erosion, non-deposition and/or sediment bypass along that surface". Understanding the underlying complexity, the unconformities presented in the current work will be limited to the geometrical relationships reflecting these periods of deposition, erosion and nondeposition based on a respective tectonic position. The time aspect of the unconformities was not the focus of this work, instead ages of the unconformities will be established tentatively from the available well data.
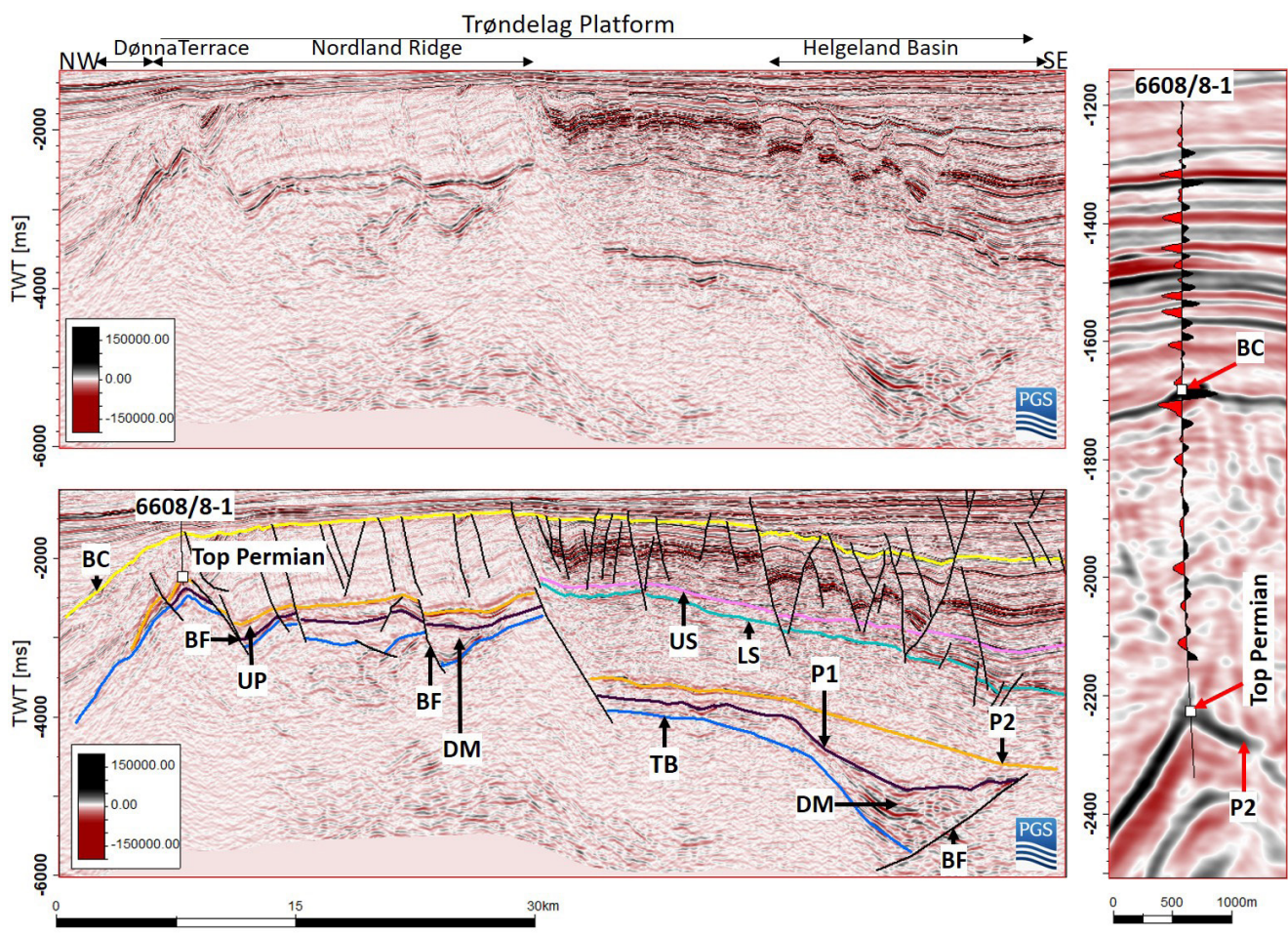

Figure 4. Uninterpreted and interpreted 3D inline 38198 of the PGS16005 survey (see Fig. 1 for location). Wellbore 6608/8-1 has penetrated the late-Permian reflector (P2). A box to the right shows a zoomed seismic area of the interval penetrated by the wellbore 6608/8-1. The P2 reflector is part of the upper Permian wedge in the Nordland Ridge. Sedimentary wedges below the upper Permian wedges (UP) are tentatively assigned an Upper Devonian-mid Permian age (DM). The base Lower Salt (LS) and top Upper Salt (US) reflectors are only present in the Helgeland Basin. Both DM and UP are fill type A shown in Fig. 5. TB - Top basement, BC-Base Cretaceous, BF-bounding fault. 


\section{Results and interpretations}

In this section, the main findings from the $3 \mathrm{D}$ and $2 \mathrm{D}$ conventional seismic interpretation will be presented using eight 2D lines and two lines from the 3D datasets (the locations of these lines are shown in Fig. 1). The other lines show similar results, and were in addition used for correlation of reflectors across the Trøndelag Platform. In the presented results, the terms positive and negative reflector stand for increased and decreased acoustic impedances, respectively.

(A)

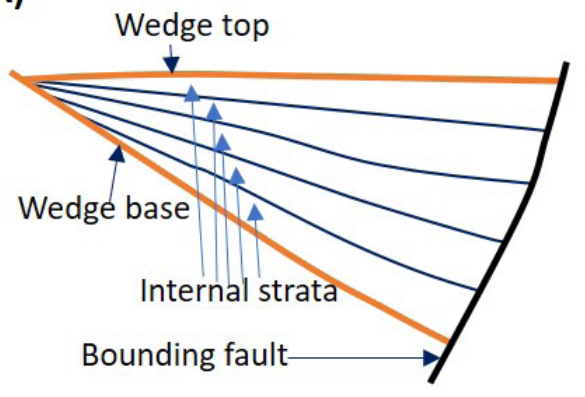

(C)

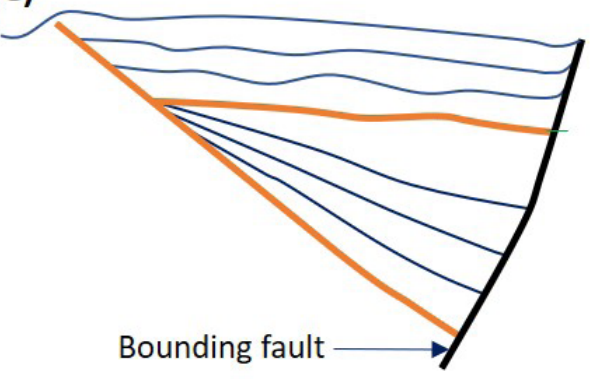

(E)

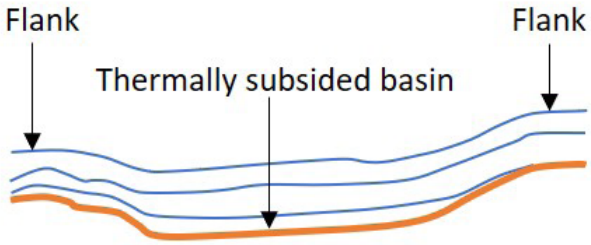

(B)

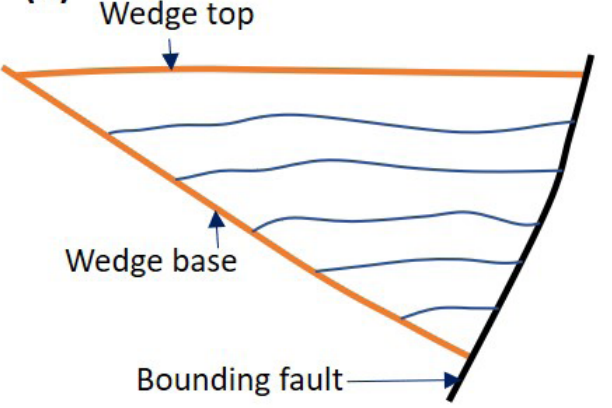

(D)

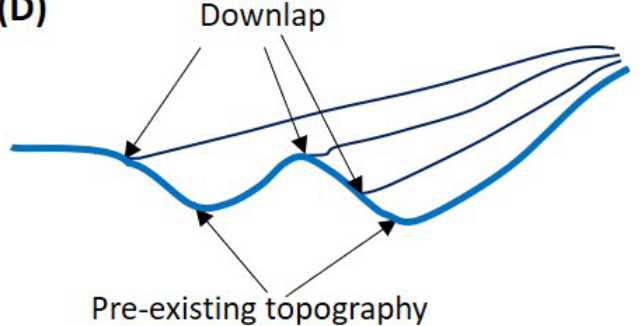

Pre-existing topography

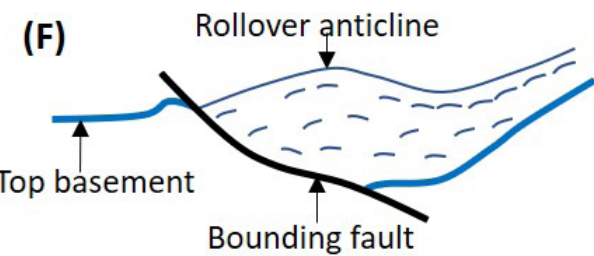

Figure 5. Cartoons illustrating different sedimentary fill geometries identified in the study area. A: syn-rift sedimentation, B: post-rift sedimentation, C: syn-rift followed by post-rift sedimentation, D: infill of existing topography, E: infill of thermally subsided basin, F: tectonic deformation after infill. See main text for discussion.

\section{Sedimentary fill types}

The interpretation of active tectonics vs. quiescent phases has been based on different basin fill geometries. The studied interval contains six sedimentary fill geometries (Fig. 5). Fill geometry A is characterised by a wedge shape, i.e. thickening of the total fill towards the bounding fault, and by a thickening of the internal strata towards the bounding fault. This stratal pattern reflects syn-rift sedimentation (Nøttvedt et al., 1995; Ravnås \& Bondevik, 1997; Steel, 1998; Elliott et al., 2017). Fill type A was recognised in the Upper Devonian-mid Permian, upper Permian-Lower Triassic and Upper Triassic successions (Figs. 4, 6, 7, 8 \& 9). 

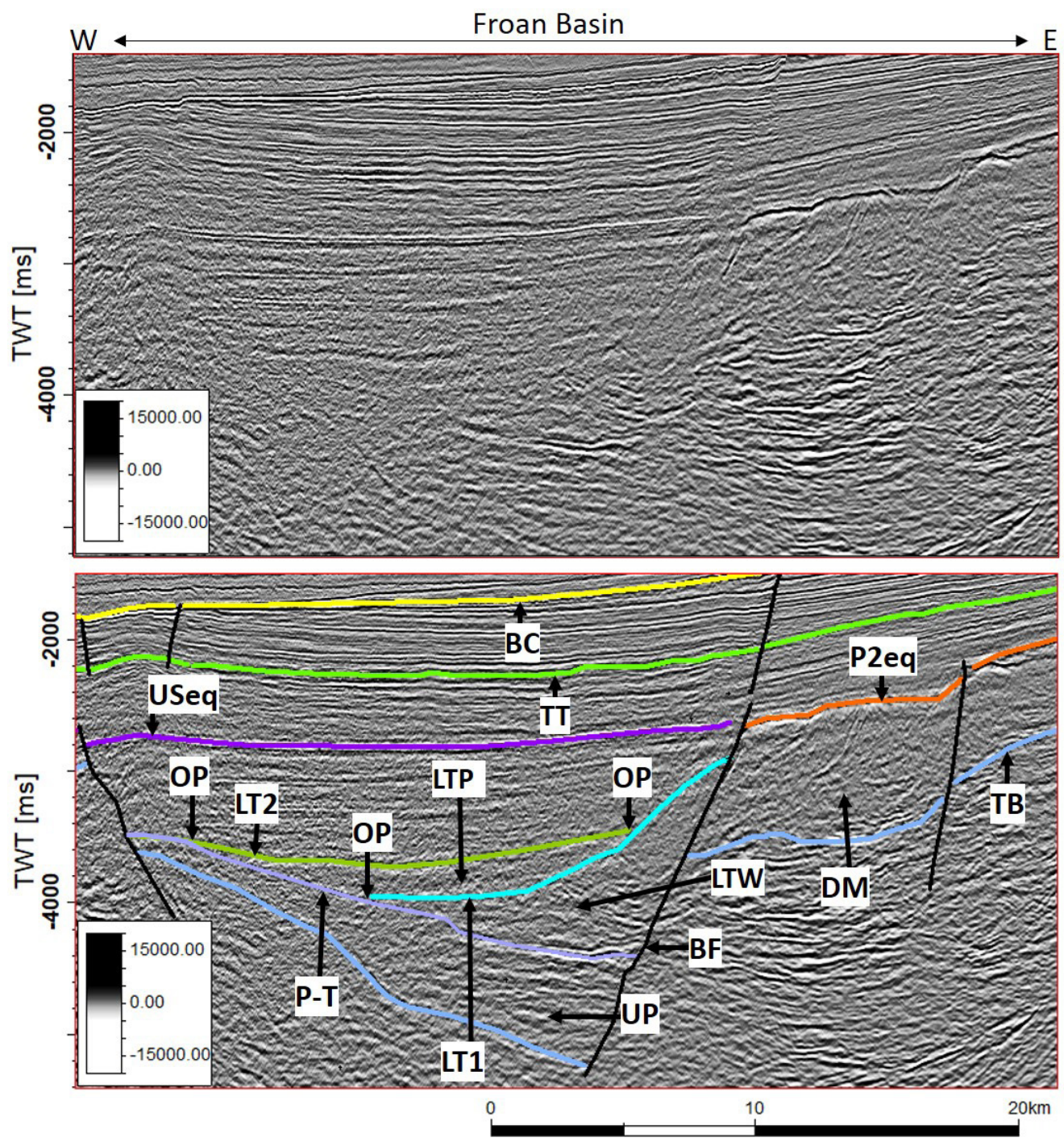

Figure 6. Uninterpreted and interpreted seismic line MNR07-7118 through the Froan Basin (see Fig. 1 for location). Both the upper Permian (UP) and Lower Triassic (LTW) wedges are bounded by a westward-dipping major fault (BF). Both UP and LTW are fill type A shown in Fig. 5. P2eq is the top of the Upper Devonian-mid Permian package (DM). The $P-T$ reflector is the top upper Permian. The Lower Triassic reflectors (LT1 and LT2) onlap onto the P-T reflector indicating that the P-T is an unconformity. LT2 onlaps onto LT1 indicating an unconformity between LT1 and LT2. The top Upper Salt equivalent reflector (USeq) has been mapped in the Froan Basin. OP - onlap, BC-base Cretaceous, TB - top basement, LTP - Lower Triassic package.

Fill type B in Fig. 5 is also wedge-shaped, but in this case the internal strata have more or less uniform thickness and are normally gently dipping to flat-lying. This pattern means that deposition did not take place during the movement of the fault but was a later process that infilled existing topography ( $N \varnothing t t v e d t$ et al., 1995). It is therefore indicative of a post-rift quiescent period. This fill type is shown by some of the Middle-Upper Triassic intervals (Fig. 10).

A third wedge type (fill type $C$ ) is a combination of fill types $A$ and $B$, where the fill is composed of two parts, with a lower part where strata thicken towards the bounding fault as shown by fill type $A$ (thus indicating fill during active fault movement), and an upper part where strata are of more or less uniform thickness (thus indicating fill after the movement on the fault had stopped but before the basin was full). This fill type is seen in the Lower Triassic and Upper Triassic intervals in the Helgeland Basin and the Nordland Ridge (Fig. 7). It is described as a separate type here as it is the only case where a basin has been filled in multiple stages. 

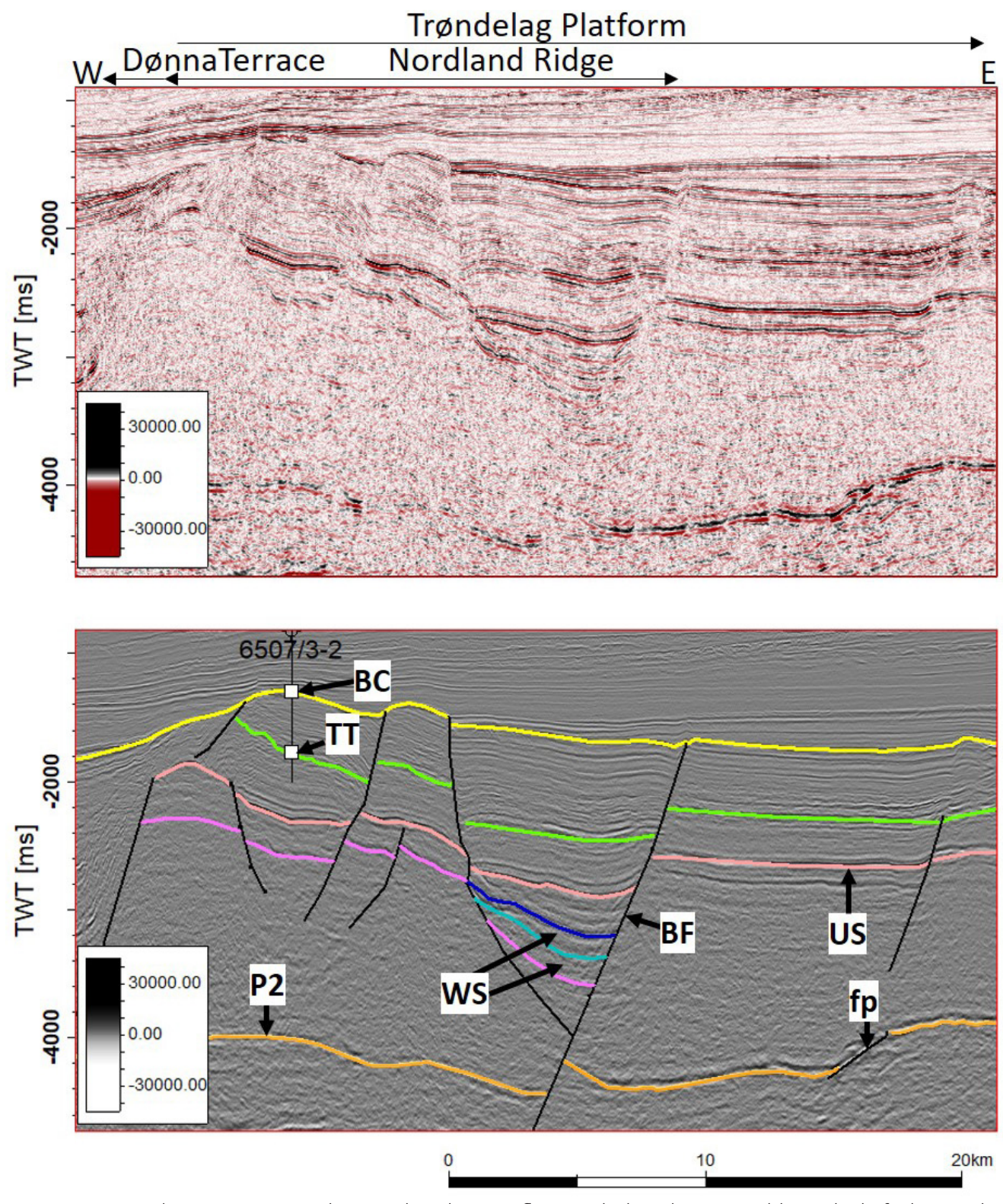

Figure 7. Seismic line MNR07-7294 showing that the P2 reflector, which is discontinued by multiple faults, can be followed all the way through the Nordland Ridge (see Fig. 1 for location). This figure also shows a sedimentary wedge thickening towards a bounding fault (BF). The wedge-internal strata (WS) up to the top Upper Salt (US) thicken towards the bounding fault as shown by fill type A in Fig. 5. The top of the wedge is marked by US; thus, the wedge is assigned to the Upper Triassic interval. The strata above the Upper Triassic wedge have uniform thickness. In this line, Triassic top (TT) and base Cretaceous (BC) ages are constrained by wellbore 6507/3-2 (see NPD, 2003 for well information). $f p$-fault that has discontinued only the P2, TB - top basement.

Fill type D in Fig. 5 shows a sedimentary fill containing strata that thicken basinward and downlap onto pre-existing topography. These strata fill lows in existing basin topography during a tectonically quiescent period. An example of this is the Upper Devonian- mid Permian fill in Fig. 11, where the strata downlap onto the basement.

Fill type E shows a sedimentary fill containing deposits interpreted to have filled a saucer-shaped depression that is not influenced by faulting. The strata are thickest in the middle of the depression and thinnest toward the flanks, which implies fill of a thermally subsided basin. This fill type has been observed in the Upper Triassic interval in the Helgeland Basin (Fig. 12). 

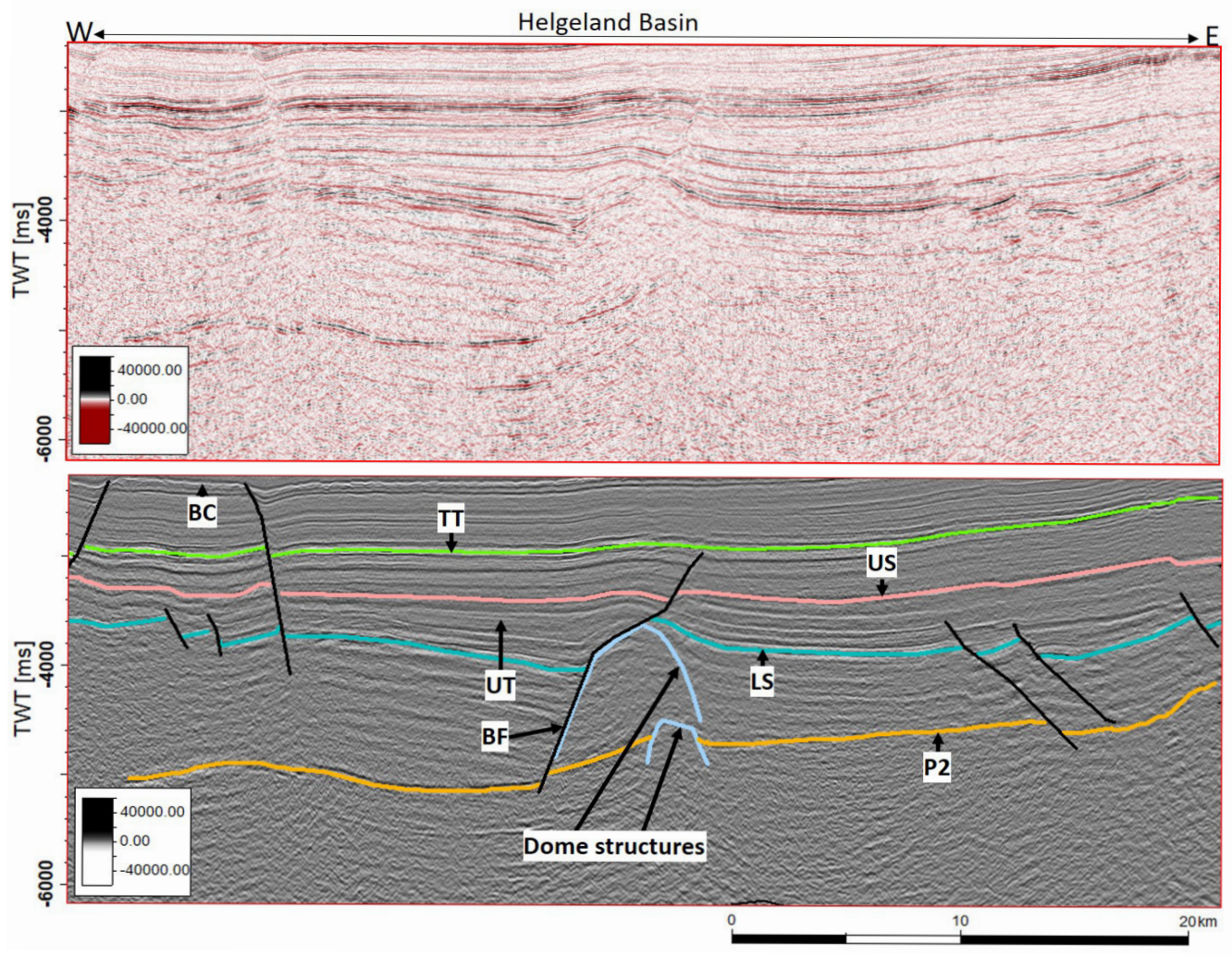

Figure 8. Uninterpreted and interpreted seismic line MNR-7314 in the Helgeland Basin (see Fig. 1 for location). Two dome-shaped structures, one on top of the other, are seen. The base Lower Salt (LS) and top Upper Salt (US) reflectors encase a sedimentary deposit (UT) that thickens towards a bounding fault (BF) as shown by fill type A in Fig. 5, although draping onto the dome structure complicates the stratal geometry. The P2 reflector and LS and US have been discontinued by the bounding fault. The bounding fault follows the surface of the upper dome structure. TT - Triassic top.

Fill type $\mathrm{F}$ is somewhat different and is characterised by rotated internal strata and has a clear folded top. The package is bounded by a rotated, low-angle fault. The folding of the entire package is due to post-fill tectonic deformation. This wedge type accommodates the Upper Devonian- mid Permian sedimentary successions (Fig. 13).

\section{Reflectors and packages}

Based on the fill types and the ages of reflectors, the following tectonic development can be seen in the Trøndelag Platform. The description focuses mostly on the indicators of active tectonic phases.

\section{Top basement}

The top of the basement is marked by a positive reflector that overlies the bottommost chaotic interval (see Fig. 6) and can be seen in the entire Trøndelag Platform (Figs. 4, 6, 9, 10, 11 \& 13). It shows varied relief, such as localised highs (Fig. 11), and is in places offset by faults (Figs. 4, 6, 9, 10 \& 13). The localised highs on the basement, which are mostly found in the Helgeland Basin (Fig. 11), show Palaeozoic basement topography. 

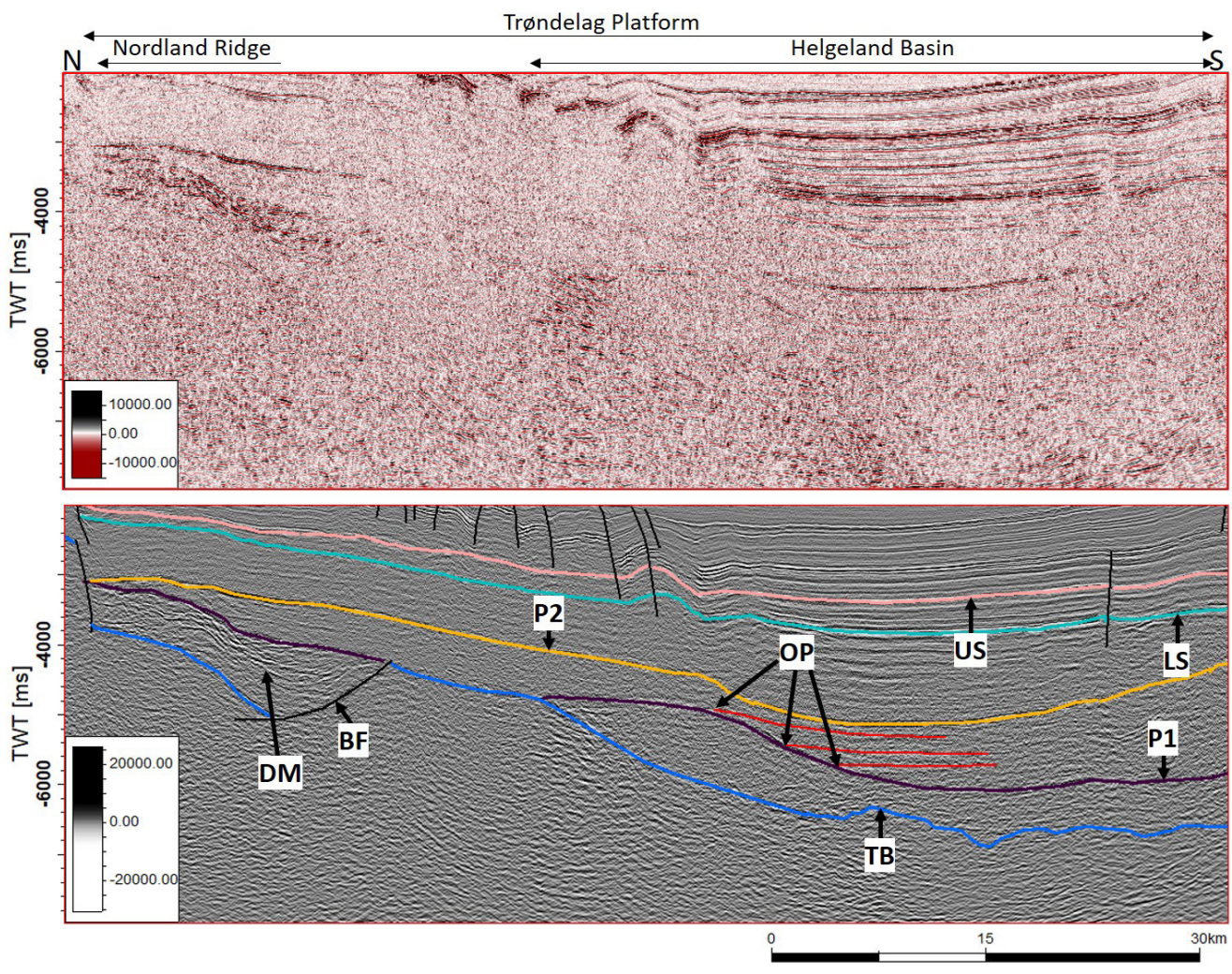

Figure 9. Seismic line MNR08-518 (uninterpreted and interpreted) showing a syn-rift wedge of Upper Devonian-mid Permian age (DM). The top basement (TB) and $P 1$ are discontinued by a bounding fault (BF). P2 is laterally more extensive than P1. P1 onlaps onto the basement (fill type D) and other reflectors (red) onlap (OP) onto the P1. The interval between the base Lower Salt (LS) and top Upper Salt (US) thins towards the Nordland Ridge and is thickest in the Helgeland Basin. DM is a fill type A shown in Fig. 5.

\section{Palaeozoic strata below the P1 reflector}

Various basin fill types can be seen in the Palaeozoic strata. The oldest Palaeozoic strata downlap onto the top basement reflector in the deeper parts of the basin in the south and southeast of the Helgeland Basin (Fig. 11) and thin out from the deep areas toward the margins of the platform (Fig. 11). This is the type of fill shown in Fig. 5D, signifying deposition onto pre-existing topography during tectonic quiescence. The Helgeland Basin and Nordland Ridge contain wedge-shaped sedimentary packages that thicken toward bounding faults (Figs. 4 \& 9). These wedges show fill type A (formed during active tectonics) of Fig. 5. South and southeast of the Helgeland Basin, Palaeozoic fill consists of a rotated wedge characterised by rotated internal strata (Fig. 13). The wedge in Fig. 13 is a type F fill of Fig. 5 (fill finished before tectonic deformation).

\section{P1 reflector}

The P1 reflector is below P2 (which is a late Permian reflector based on the well tie in Fig. 4). In the northern part of the Trøndelag Platform (including the Nordland Ridge and the Helgeland Basin), P1 is a high-amplitude discontinuous reflector that marks the top of the various fill types described above. Some weak reflectors are observed onlapping onto the P1 reflector in the Helgeland Basin (Fig. 9). The combination of overlain basins with different fill types and onlap onto the reflector indicates that P1 is an erosional surface. Because P1 is below P2 in every area where both of them are present, including 

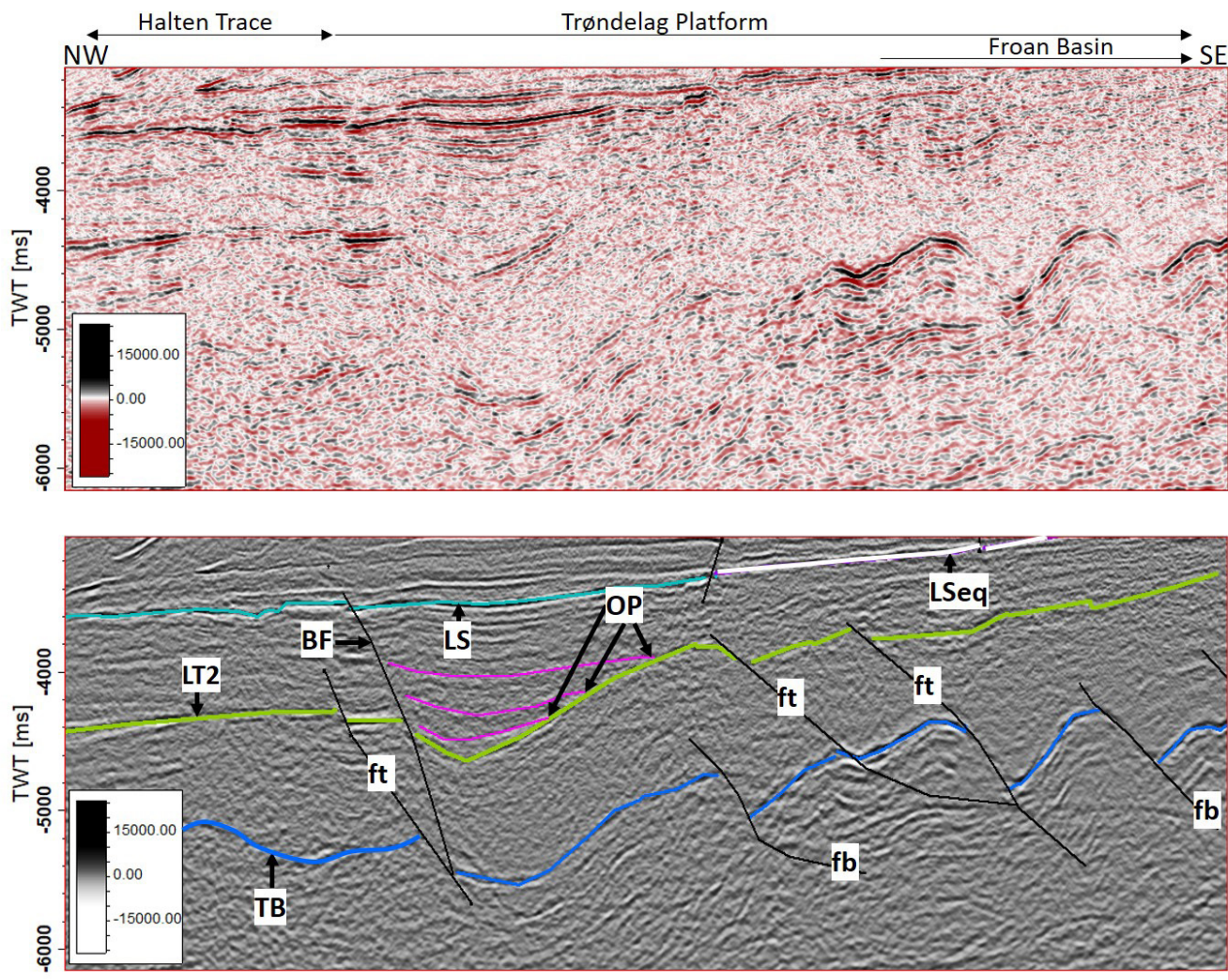

\section{0}

Figure 10. Uninterpreted and interpreted seismic line MNR11-90507 through the Trøndelag Platform (see Fig. 1 for location). Pink reflectors onlap (OP) onto the LT2 reflector, indicating fill type B of Fig. 5. The base Lower Salt (LS) and the overlying strata are characterised by more or less gently dipping strata of uniform thickness. fb - faults that have displaced only the top basement, ft - faults that have displaced the top basement-Lower Triassic reflectors, TB - top basement and LSeq is an equivalent of the base Lower Salt reflector in the Froan Basin.

in locations with well ties, and because it is an onlap surface, it is thought to mark the mid Permian unconformity which has also been found in eastern Greenland (Fig. 2).

\section{P2 reflector}

The P2 is a high-amplitude reflector in the Trøndelag Platform. The P2 appears as a negative reflector in the well tie in Fig. 3A but it was traced as a strong positive reflector in the well tie in Fig. 4 . That is, the P2 reflector shows intensity variation and polarity change from strongly positive in some parts of the Nordland Ridge (Fig. 4) to strongly negative in most of the central part of the Helgeland Basin (Fig. 7). Fig. 4 shows a good example of P2 dimming, where the intensity of the reflector decreases as it approaches the sedimentary wedge in the southeastern part of the seismic line in the Helgeland Basin. The intensity variation of the P2 reflector is attributed to the fact that the P2 overlies multiple rock units with different petrophysical properties. The P2 reflector overlies at least four different rock units (units 1-4) as described in the discussion.

The P2 reflector is generally laterally extensive in most of the northern part of the Trøndelag Platform (Figs. 7 \& 11), although it is locally discontinuous. For example, it can be followed from west to east across the Helgeland Basin and in some parts of the Nordland Ridge (Fig. 7). The P2 reflector cannot be traced directly from the Helgeland Basin to the Froan Basin but an equivalent reflector in the same 

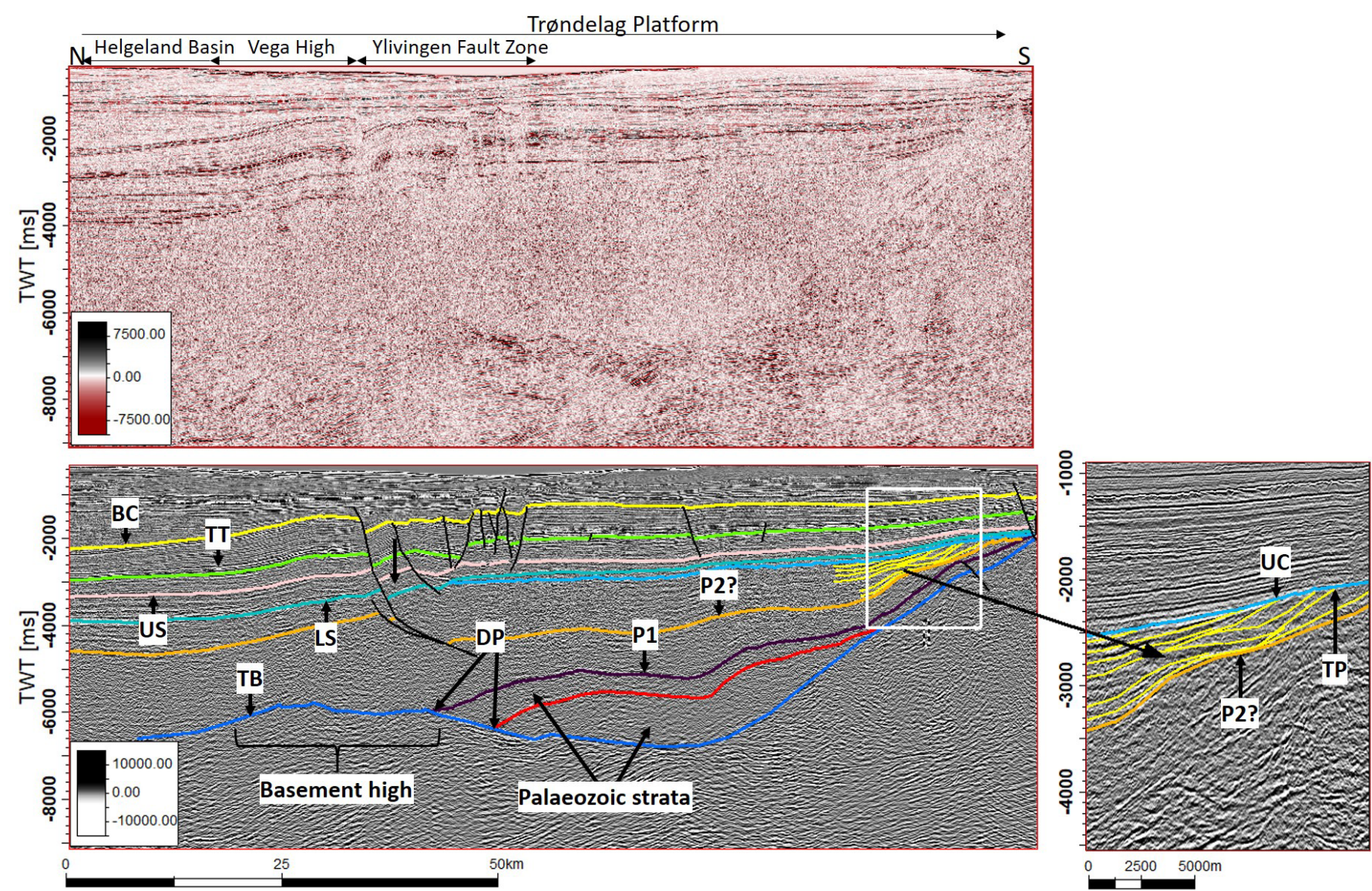

Figure 11. Seismic line MNR07-540 (uninterpreted and interpreted lines) through the Trøndelag Platform (see Fig. 1 for location) showing southward thinning of Palaeozoic strata which downlap (DP) onto the top of the basement (TB) in deeper areas (fill type D in Fig. 5). An interval between the base Lower Salt (LS) and top Upper Salt (US) also thins southward towards a structural high. The inset shows reflectors (yellow) that toplap (TP) at the Middle Triassic unconformity (UC) reflector. $T T$ - top Triassic. A question mark is used where the $P 2$ position is uncertain.

stratigraphic position and with the same amplitude characteristics is found in the Froan Basin. This equivalent reflector has been named P2eq (Fig. 6). The P2eq is a high-amplitude positive reflector overlying the Upper Devonian-mid Permian package in the Froan Basin (Fig. 6).

Sedimentary wedges (fill type C) containing P2 are interpreted to contain upper Permian successions because P2 is the late Permian reflector (see Fig. 4). In the Helgeland Basin and the Nordland Ridge, the reflectors above P2 are more or less parallel (Fig. 4). An example of this is the uniform thickness of the sedimentary layers between P2 and the base of the Lower Salt from the southeastern end of the Nordland Ridge to the Helgeland Basin (Fig. 4). Such a sedimentary configuration indicates a change from syn-rift sedimentation during the late Permian, as illustrated by fault-ward thickening strata immediately below P2 (e.g., UP in Fig. 4), to post-rift sedimentation characterised by more or less uniform thickness strata (fill type B) during the Lower Triassic- Middle Triassic.

\section{$\mathrm{P}-\mathrm{T}$ reflector}

The P-T reflector is identified in the Froan Basin (Fig. 6), as a negative low-amplitude reflector, where it marks the top of an upper Permian wedge-shaped sedimentary package (fill type A). The P-T reflector was difficult to follow with certainty in most of the seismic profiles. It is interpreted as the PermoTriassic boundary because it marks the top of the upper Permian wedge, although as mentioned by 

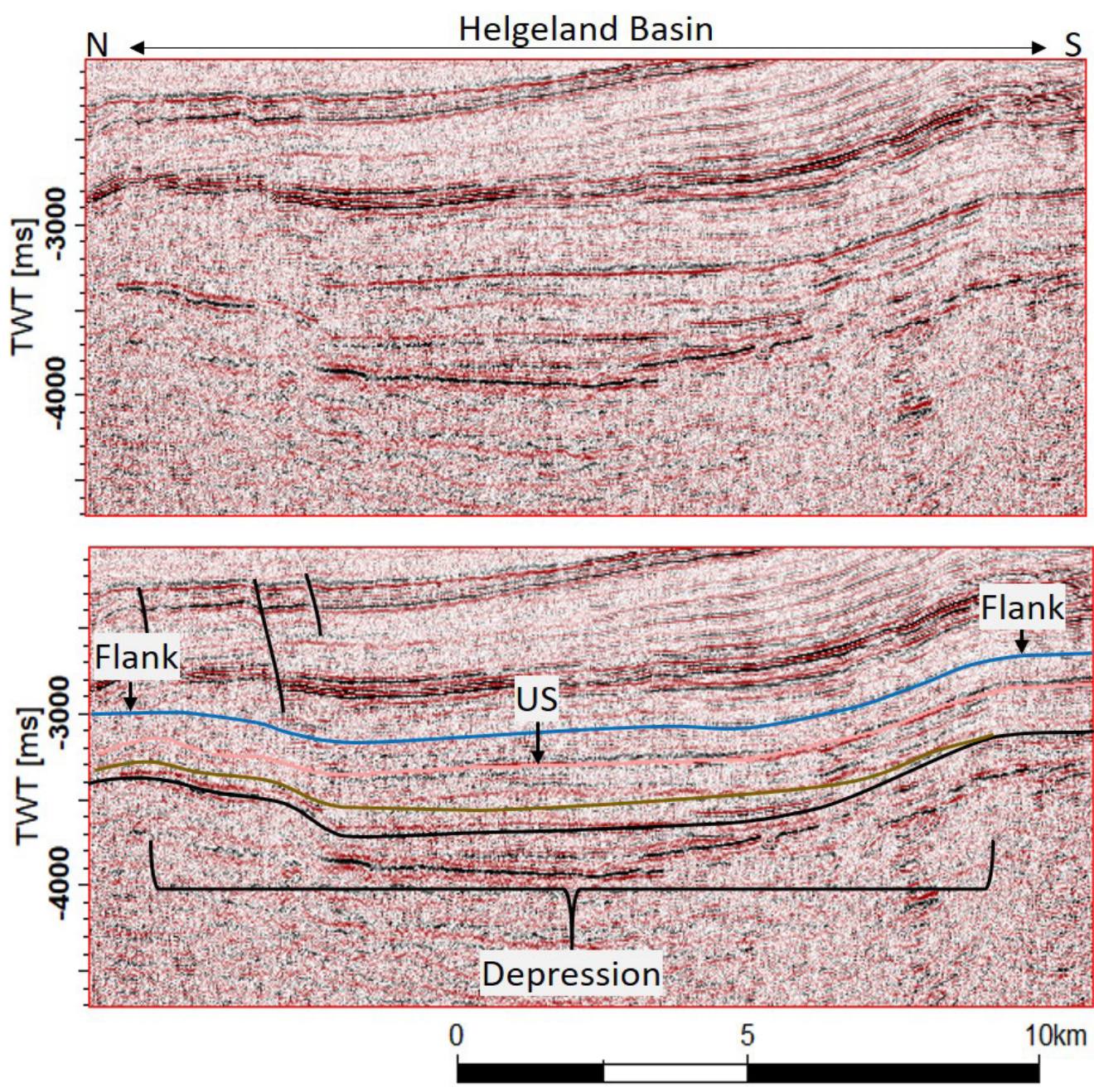

Figure 12. Top and bottom images show uninterpreted and interpreted parts, respectively, of seismic line MNR07-540 in the Helgeland Basin. The section shows a depression filled by sedimentary deposits. The Upper Salt is part of the successions filling the depression. Other reflectors were traced to show the depression geometry. The depression has a thick sedimentary package in the middle and thin deposits at the flanks. This is fill type E in Fig. 5.

Bugge et al. (2002) it is difficult to be clear about the exact depth of this stratigraphic boundary. The $\mathrm{P}-\mathrm{T}$ reflector is an unconformity since other reflectors onlap onto it (Fig. 6). There is an equivalent P-T reflector in the Helgeland Basin, but it is difficult to follow.

\section{LT1 reflector}

The LT1 is a negative low-amplitude reflector that is only present in the Froan Basin (Fig. 6). It overlies a steeply dipping wedge that thickens towards the bounding fault (fill type A of Fig. 5, fill during active tectonics). The LT1 onlaps onto both the P-T reflector and the bounding fault. The steeply dipping wedge is assigned a Lower Triassic age because it is just above the upper Permian wedge (LTW in Fig. 6).

\section{LT2 reflector}

The LT2, a negative low-amplitude reflector, is only present in the Froan Basin and onlaps onto the P-T and LT1 reflectors (Fig. 6). LT2 is the top of the Lower Triassic fill (LTP) that overlies the steeply dipping 

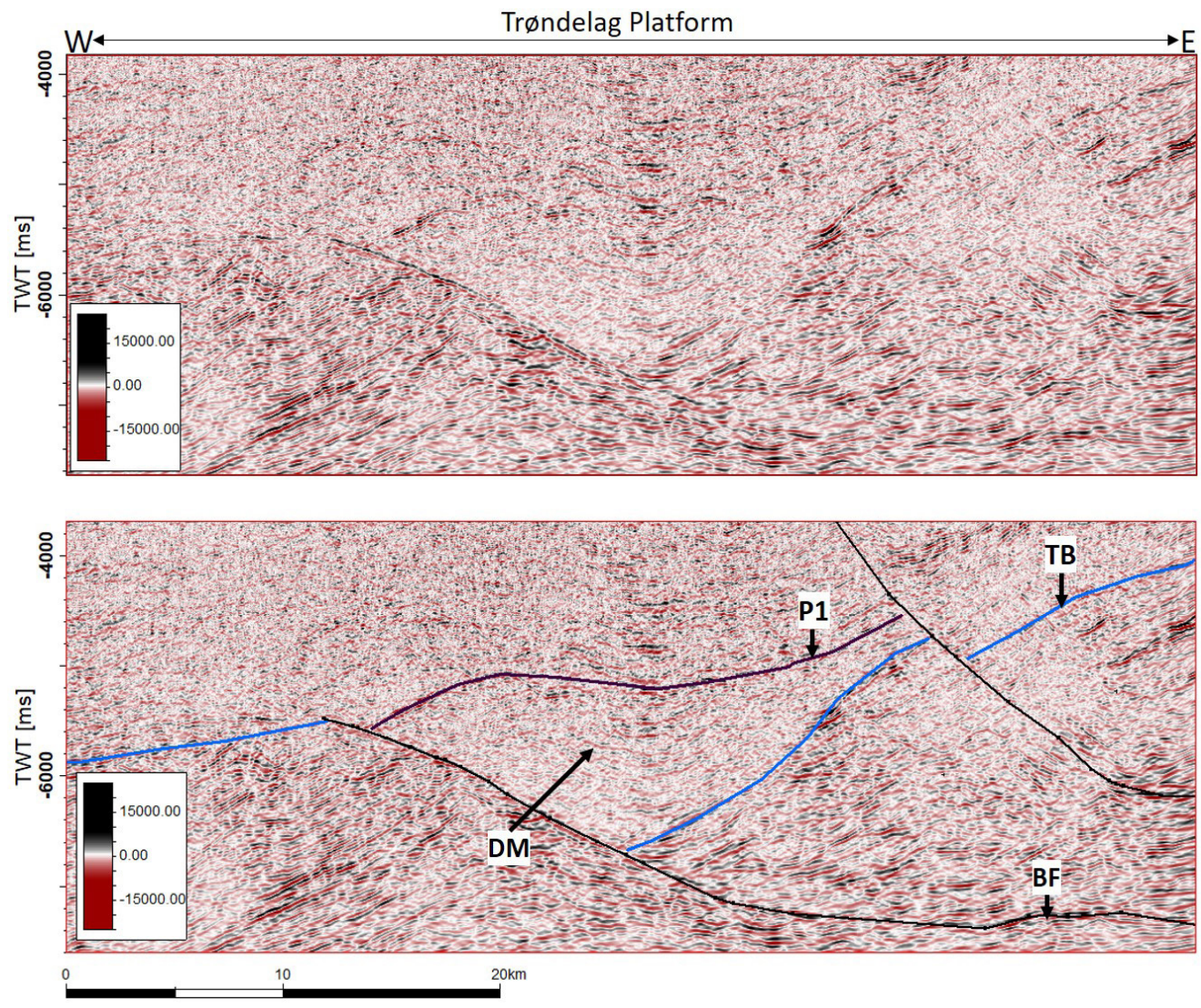

Figure 13. Top and bottom images show uninterpreted and interpreted seismic line MNR06-7260, respectively (see Fig. 1 for location). The Upper Devonian-mid Permian wedge (DM) is bounded by a low angle fault (BF) and contains weak internal reflectors that are rotated (fill type F in Fig. 5). The P1 reflector is weakly folded, marks the top of the upper Devonian-mid Permian wedge and onlaps onto the bounding fault.

wedge fill (LTW) in Fig. 6. The LT2 reflector marks the top of the Lower Triassic fill which dips in the same direction as the LTW (Fig. 6). The onlap relations shown by the LT1 and LT2 reflectors indicate either different depositional time, non-deposition and/or erosion, or renewed tectonics.

\section{Middle Triassic}

A positive, high-amplitude, toplap reflector is observed in the Trøndelag Platform to the north of the Froan Basin, indicating an angular unconformity. The toplap reflector is a gently northward-dipping surface with high amplitude just below the base of the Lower Salt (Fig. 11). The well tie in Fig. 3 B gives a Middle Triassic age for the base of the Lower Salt, and thus the toplap surface is interpreted to be of Middle Triassic age in the Trøndelag Platform north of the Froan Basin. Reflectors which toplap onto the Middle Triassic unconformity are stratigraphically between the late Permian reflector (P2) and the unconformity (Fig. 11).

\section{Upper Triassic}

The base of the Lower Salt is marked by a discontinuous, positive, high-amplitude reflector (Figs. 3B \& 4). The top Upper Salt is marked by a discontinuous, negative, high-amplitude reflector (Figs. 3B \& 4). No salt deposit has been penetrated by wellbores just to the north of the Froan Basin, but the equivalents 
(in terms of amplitude characteristics and stratigraphic positions) of the base Lower Salt (LSeq) and top Upper Salt (USeq) reflectors can be followed southwards to the Froan Basin (Figs. 6 \& 10). In the Frøya High (see Fig. 1 for well location), the USeq overlies a shaly interval penetrated by wellbore 6407/10-3 (NPD, 2004a) rather than Upper Salt, hence the designation as an equivalent reflector in the Froan Basin. In the central and northern parts of the Trøndelag Platform, the salt layers thin out toward the structural highs (Figs. 9 \& 11): the salt deposits are thickest in the parts farthest away from the shoreline and away from the platform highs. This seismic pattern agrees with well data since correlation between wellbores 6507/12-2 and 6507/12-1 has shown that all layers (thus including the salt layers) thin toward the edges of the Trøndelag Platform (NPD, 2004b). Sedimentary wedges in Figs. 7 \& 8 (fill type A of Fig. 5, fill during active tectonics) are Middle-Upper Triassic deposits because they are encased between the Lower and Upper Salts that are of late Mid-Triassic to early Late-Triassic age (see the well tie in Fig. 3B).

\section{Dome-shaped structures}

The new seismic data show previously undetected dome structures in the deep part of the Helgeland Basin. Two isolated dome-shaped structures, one on top of the other (Fig. 8), are observed on three seismic lines in the Helgeland Basin, about $83 \mathrm{~km}$ west of the present Norwegian coastline. The lower structure is a topographic relief beneath the upper structure. The bases of these structures are within the Carboniferous-Permian deposits of the Helgeland Basin while the top of the upper structure is within the Upper Triassic strata and ends just below the top Lower Salt reflector. The structures show vertical zones of deteriorated seismic quality. These dome-shaped structures can be traced up to about $16 \mathrm{~km}$ in a N-S orientation and about $7.5 \mathrm{~km} \mathrm{E-W}$. The upper structure is wider than the lower structure. Both dome-shaped structures have steep slopes. Reflectors onlap onto these structures (for example, the P2 reflector onlaps onto the lower structure). At the top of the structure a monocline is observed in faulted superjacent strata.

\section{Faults}

Large-scale faults occur in the study area. They displaced the major reflectors and influence the basin fill patterns. These are the faults active before the late Permian, late Permian faults, and late PermianTriassic faults. The name of a fault reflects the age of the section that was displaced when the fault was active. For example, the sedimentary wedge in Fig. 8 is confined between the salt reflectors. These salts are of late Mid Triassic to early Late Triassic age (Jacobsen \& van Veen, 1984; Müller et al., 2005); thus, the bounding fault is named late Triassic fault due to the age of the salt layers.

Faults that were active before the late Permian displaced the top of the basement and bound the Upper Devonian-mid and upper Permian strata (Figs. 4 \& 13). These faults are bounding faults for fill types A and F of Fig. 5. The bounding faults for the Upper Devonian-mid Permian sedimentary wedges in the deeper parts of the Trøndelag Platform are flatter than other faults (Figs. 4 \& 13).

All faults that have discontinued only the P2 reflector (Fig. 7) are named late Permian faults. These faults have been found only in the Helgeland Basin. The late Permian-Triassic faults bound the upper Permian wedges and Lower Triassic packages (Fig. 6) indicating fault activity during the Permo-Triassic (fill type A of Fig. 5, fill during active tectonics). 


\section{Discussion}

\section{Dome structures}

It is not immediately clear what the dome-shaped structures are that are present in strata of Carboniferous to Lower Triassic age in the Helgeland Basin (Fig. 8). Based on observations in areas offshore Norway, one of the two following explanations is most likely. The first possible explanation is that the structures are intrusions. The mid Norway-eastern Greenland separation was accompanied by widespread volcanism during the Palaeocene to Eocene that led to several intrusive magmatic bodies in the Frøya High and the Møre and Vøring basins (Prestvik et al., 1999; Brekke, 2000). However, several intrusion-induced features were not observed in the analysed seismic images. Missing features include minor faulting (but still observable on seismic) of the immediate strata above the intrusion (Zhao et al., 2014; Zhao et al., 2016) which occurred during intrusion (only a major fault is seen), or saucer and eye-shaped structures (e.g., Brekke, 2000; Hansen et al., 2007).

The second possible explanation is that the structures are isolated carbonate build-ups, as the structures show multiple features described by Burgess et al. (2013) to identify such build-ups. CarboniferousPermian carbonates and carbonate build-ups are known from the Barents Sea (Stemmerik et al., 1999; Elvebakk et al., 2002), the Nordland Ridge (Bugge et al., 2002), eastern Greenland (Surlyk, 1990), and from fragments in the turbidite units (Bugge et al., 2002). The depositional conditions were therefore conducive for carbonate deposition and the domes may be Carboniferous-Permian carbonate build-ups that formed positive relief over which late Permian and Triassic sediments were deposited. From the criteria given by Burgess et al. (2013), the following are observed here. Both dome structures have steep margins. Strata overlying the domes are faulted and folded by a fault that displaces upper PermianUpper Triassic strata and thus postdates the domes. The faulting and folding are probably due to differential compaction; early cementation of carbonates in the area (Bugge et al., 2002) means that the build-ups would have been more resistant to compaction and faulting as compared with the surrounding deposits. The build-ups in turn formed local highs causing onlap of later deposits, for example the P2 reflector (Fig. 8). The stacking of the two domes indicates a long-lived location, as also found in the Barents Sea by Elvebakk et al. (2002). In addition to the geometric criteria, the width of the structures (about 7.5 and $16 \mathrm{~km}$ for the lower and upper structure, respectively) fall within the ranges of known carbonate build-ups given by Burgess et al. (2013).

If the interpretation of isolated Carboniferous-Permian carbonate build-ups is correct, then this shows that carbonates were widespread throughout the area during the initial opening of the seaway, extending to East Greenland and the Barents Sea. It is possible that more Carboniferous-Permian carbonate build-ups exist in the area, but it was not possible to identify any more due to the limited quality of the seismic dataset. Absence of these carbonates in the Triassic interval may have been caused by an increased clastic supply due to multiple gravity flows that dominated the area during the late Permian- Early Triassic (Bugge et al., 2002) and continued drowning of the area due to late Permian- Early Triassic transgression (Surlyk et al., 1984; Doré, 1992). However, more research will be needed to confirm whether these structures are carbonates, or whether they are intrusions, or something else. 


\section{P2 reflector intensity}

The intensity of the late Permian reflector P2 diminishes toward the sub-basins of the Trøndelag Platform area (Fig. 4) due to lateral variation in lithological properties. The P2 reflector is interpreted to overlie multiple sedimentary units and that is why its intensity varies, and polarity is reversed, from place to place. A conceptual model was created to show the distribution of these units in the study area (Fig. 14). These units are named units 1-4 and their distributions were based on well reports, the Permo-Triassic deposition model of mid Norway and eastern Greenland of Bugge et al. (2002) and the presence of Upper Devonian sedimentary rocks offshore and onshore mid Norway (Bugge et al., 2002; Osmundsen et al., 2006). Unit 1 contains the Upper Devonian strata and is present in the eastern Trøndelag Platform as inferred from Fig. 6 . Devonian clastic strata are documented onshore, directly east of the current study area (Osmundsen et al., 2006). Devonian continental environments were continuous across the area before rifting, and Devonian deposits are present on both sides of the Norway-Greenland seaway (Osmundsen et al., 2006; Guarnieri et al., 2017), so are likely to be present (although unproven) in the interior of the Nordland Ridge (Fig. 4) and Frøya High. Unit 2 consists of upper Permian organic-carbon-rich sediments, based on the description of core 6611/09-U-01 by Bugge et al. (2002) and on the core 6507/6-4 A report (NPD, 2013). Core 6507/6-4 A penetrated sedimentary successions that are age-equivalent to PermoTriassic deposits in core 6611/09-U-01 (NPD, 2013) as indicated in Fig. 2. Unit 3 contains upper Permian carbonates. Upper Permian carbonates have been penetrated by wellbores 6609/7-1 and 6608/8-1 (Bugge et al., 2002; Müller et al., 2005) on the Nordland Ridge (see Fig. 1 for locations). Interfingering of units 2 and 3 is based on the Permo-Triassic depositional model of Bugge et al. (2002). Unit 4 contains the Anhydrite Unit of Bugge et al. (2002). Units 1, 3 and 4 have higher acoustic impedance than unit 2. The units directly above the upper Permian are organic poor (Bugge et al., 2002), thus all successions above $\mathrm{P} 2$ can be assumed to have high acoustic impedance. As a result, the $\mathrm{P} 2$ is a strong positive reflector when overlying units 1,3 and 4 . The $\mathrm{P} 2$ is a strong negative reflector when overlying unit 2 because unit 2 is an organic-rich interval with low acoustic impedance and consequently negative reflection.

\section{Tectonic phases and unconformities}

Table 1 summarises the Devonian-Triassic unconformities and rifting events that have controlled sedimentation in the study area. The details of these tectonic phases and unconformities are discussed below.

\section{Devonian-Permian}

The late Palaeozoic sub-basins in the Norway-Greenland basin were formed during early extension regimes that led to the initial opening of the Atlantic Ocean (Surlyk et al., 1984). Rifting is reported to have occurred in the southwestern Barents Sea during the mid Carboniferous (Gudlaugsson et al., 1998). This rifting episode formed a rift zone that was about $300 \mathrm{~km}$ wide and at least $600 \mathrm{~km}$ long and was a direct continuation of the northeast Atlantic rift between Greenland and Norway (Gudlaugsson et al., 1998). This continuation suggests that the Devonian-Permian rift occurred on a regional scale.

Different aspects of this period of rifting have also been recognised in this work, but not all parts of the Trøndelag platform were affected in the same way. The rifting may have resulted in the basement unconformity shown by the downlap of the Permian strata. Brekke (2000) stated that an early-Permian unconformity can be identified in the platform area but did not give further description or supporting 
references for this. The basement unconformity seen here may be this early Permian unconformity, and it has been mapped in the Nordland Ridge, Helgeland Basin and in the area between the Helgeland and Froan basins. The fact that the bounding faults for the Palaeozoic wedges (Figs. 4 \& 13) are flatter than other bounding faults suggests either that basement rotation occurred during the Palaeozoic or the presence of low-angle normal faults in the study area. The presence of low-angle normal faults, which have been linked to metamorphic core complexes by Webber et al. (2018), is the most likely interpretation because metamorphic core complexes are present in the study area (see Osmundsen et al., 2005). Formation of these core complexes may have created the basin topography that accommodated Palaeozoic sedimentary fills in the Trøndelag Platform. These Palaeozoic fills thicken toward the deeper parts of the Trøndelag Platform and onlap onto the basement floor (Fig. 11, fill type D of Fig. 5).

The current study has identified Devonian- Permian rift features as indicated by the Upper Devonian- mid Permian wedges that thicken towards the bounding faults (fill type A of Fig. 5) in the Trøndelag Platform (Fig. 4). The Devonian-Permian tectonic events have been reported before (e.g., Blystad et al., 1995) but data and their exact locations in the Trøndelag Platform were not shown. Rifting features of this age are found in most of the central-eastern Trøndelag Platform, to the north of the Froan Basin, in the Nordland Ridge and in a small area to the northwest of the Helgeland Basin (Figs. 4 \& 9). The widespread distribution of these features implies rift influence over the entire northern Trøndelag Platform. During the Devonian-Permian rift phase, structural highs could have formed that acted as nucleation sites for carbonate build-ups.

\section{Mid Permian}

The second regional tectonic phase has been reported to have taken place during the middle Permian (Brekke et al., 2001). Rifting and erosion characterised the mid Permian in both eastern Greenland, where an extensive mid Permian unconformity has been reported (e.g., Surlyk et al., 1984; Surlyk, 1990; Seidler, 2000; Oftedal et al., 2005; Guarnieri et al., 2017), and the mid-Norwegian shelf (Doré, 1992). This unconformity had not been well mapped offshore Mid Norway so far.

The P1 reflector is the expression of this tectonic phase in the Trøndelag Platform. The new 3D seismic allowed mapping of this reflector in the Nordland Ridge, Helgeland Basin and in the area between the Helgeland Basin and the Froan Basin. The improved data quality allowed the reflector to be followed from the Norland Ridge to the Helgeland Basin (Fig. 4). That P1 is an unconformity is shown by the onlap of weak reflectors onto the P1 reflector (Fig. 9), indicating either erosion or non-deposition and consequently an unconformity, basin tilting after deposition, or both. Basin tilting after deposition indicates rifting during the mid Permian.

\section{Late Permian}

The late Permian tectonic phase affected the entire Trøndelag Platform. Late Permian faults and syn-rift deposits, which have been reported previously (Müller et al., 2005), have been mapped in more detail due to the availability of new high-quality 3D data. The 3D data allowed identification of late Permian rift features (faults and syn-rift deposits) in the Nordland Ridge and the tracing of these features from the Nordland Ridge to the deeper parts of the Helgeland Basin (see Fig. 4), thus showing their widespread occurrence which was not clear before. The late-Permian rift features (upper Permian wedges, fill type A) are also found in the Froan Basin (Fig. 6) showing that the late-Permian tectonic event occurred over all parts of the Trøndelag Platform. In the study area, the occurrence of rifting during the late Permian is also indicated by the late-Permian faults (Fig. 7). These faults have been interpreted to indicate a late-Permian tectonic event because they only displace the $\mathrm{P} 2$ reflector. 


\section{Early Triassic}

Müller et al. (2005) reported an Early Triassic rifting event offshore Mid Norway while two Early Triassic marine rifting events have been reported from outcrops in eastern Greenland (Seidler et al., 2004). In the current work, two Early Triassic rift phases were recognised in the Froan Basin in contrast to the one which has been reported previously (Müller et al., 2005).

The two Lower Triassic unconformities were mapped in the Froan Basin based on the onlap relationships between the P-T, LT1 and LT2 reflectors. Both LT1 and P-T reflectors are onlap surfaces interpreted to represent unconformities sensu Mitchum et al. (1977). The onlapping of LT1 onto the P-T reflector is comparable to the merging unconformities of Kyrkjeb $\varnothing$ et al. (2004). The possible existence of a hiatus between Permian and Triassic deposits (in the Helgeland Basin) has also been discussed by Bugge et al. (2002) and Müller et al. (2005) based on descriptions of core data, but here it cannot be differentiated to which of the two Froan Basin unconformities the hiatus in the Helgeland Basin corresponds. Another hiatus is proposed between the two Lower Triassic packages shown in Fig. 6 based on the onlap relationship between them. Onlapping of the Lower Triassic package onto the Lower Triassic wedge suggests the existence of an unconformity between the two Lower Triassic intervals. These two onlaps indicate the existence of two Early Triassic unconformities in the Froan Basin (Table 1).

Two explanations are possible for the presence of one Early Triassic rift feature (fill type A of Fig. 5) in the Helgeland Basin (Müller et al., 2005), instead of the two rift features (syn-rift deposits and faults) found in the Froan Basin. The first possible explanation is that one of the two Early Triassic rifts did not occur in all sub-basins in the Norway-Greenland Basin. The second possible explanation is that the two rifts occurred over the entire Trøndelag Platform but one of them could not be identified in the Helgeland Basin due to these rift features being thin and below resolution of the current seismic dataset. Further analysis on cores penetrating the Lower Triassic interval will be necessary to confirm the presence / absence of the second Early Triassic syn-rift deposits and faults in the Helgeland Basin; otherwise just one Early Triassic rifting episode is considered to have occurred there suggesting localisation of tectonic events during that time.

The LT1 and LT2 could not be traced to the Helgeland Basin because they occur in the isolated sub-basins in the Froan Basin, but age-equivalent deposits exist since the Lower Triassic sedimentary successions are present in the Helgeland Basin (Bugge et al., 2002; Müller et al., 2005).

\section{Middle-Late Triassic}

A local Middle Triassic unconformity limited to the Trøndelag Platform was mentioned by Brekke (2000) without supporting evidence. A Middle Triassic angular unconformity is shown in the current work by the toplap of Lower-Middle Triassic strata against the Middle Triassic reflector at the southern margin of the Helgeland Basin (Fig. 11), north of the Froan Basin.

Block faulting is reported to have occurred during the Mid-Late Triassic to the east of the Nordland Ridge and the Frøya High (Blystad et al., 1995) indicating a Mid-Late Triassic tectonic event. In the current work, Mid-Late Triassic rift features are mapped in the Helgeland Basin and the Nordland Ridge. The Middle-Late Triassic rifting is indicated by the sedimentary wedges (Figs. $7 \&$ 8) indicative of syn-rift sedimentation (fill type A of Fig. 5). These rift features were not found in the Froan Basin, implying a localised rift event within the Trøndelag Platform. Internal strata of the Upper Triassic wedge that drape onto the upper dome (Fig. 8) imply a change from late syn-rift to early post-rift stage. Such changes were explained by Prosser (1993), although dome structures were not part of Prosser's (1993) explanation. The presence of saucer-shaped fills in the Helgeland Basin (Fig. 12) suggests that the late Triassic rifting was followed by a period of thermal subsidence. This localised thermal subsidence indication agrees with localisation of the Middle Triassic rift phase in the Helgeland Basin. 


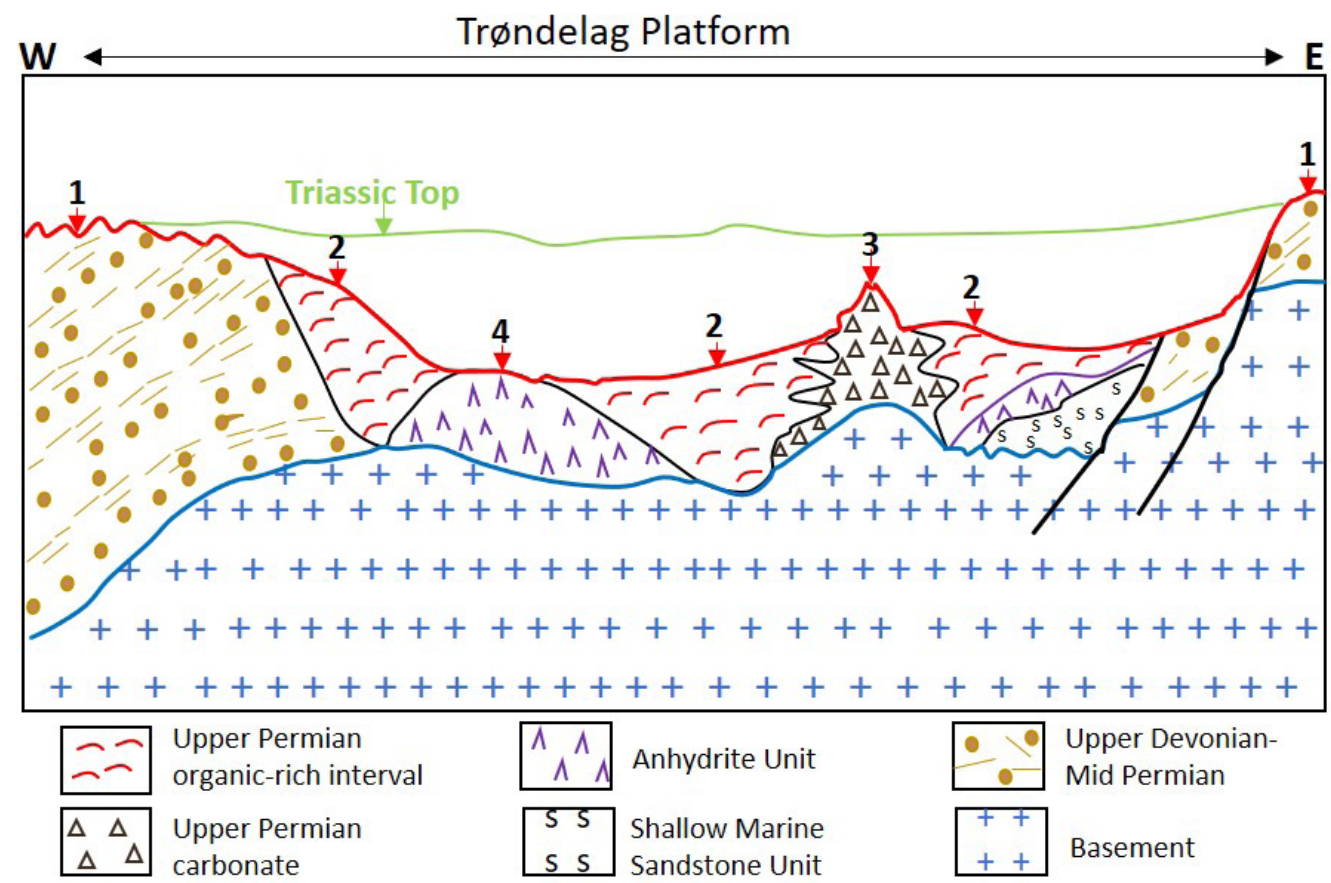

Figure 14. Conceptual Permo- Triassic depositional model for the Trøndelag Platfprm showing distribution of the P2 reflector (thick red line). This figure is not to scale. The intensity of the P2 varies depending on what unit is below it. P2 is thought to overlie four different units (1, 2, 3 and 4) which are explained in the main text. The presence of these units is based on NPD wellbore reports, similarities with eastern Greenland, Bugge et al. (2002) and Osmundsen et al. (2006).

Table 1. Late Carboniferous-Triassic tectonic phases and unconformities. The unconformities are marked by zigzag lines. Blue arrows show spans of the rift episodes 1 and 6.

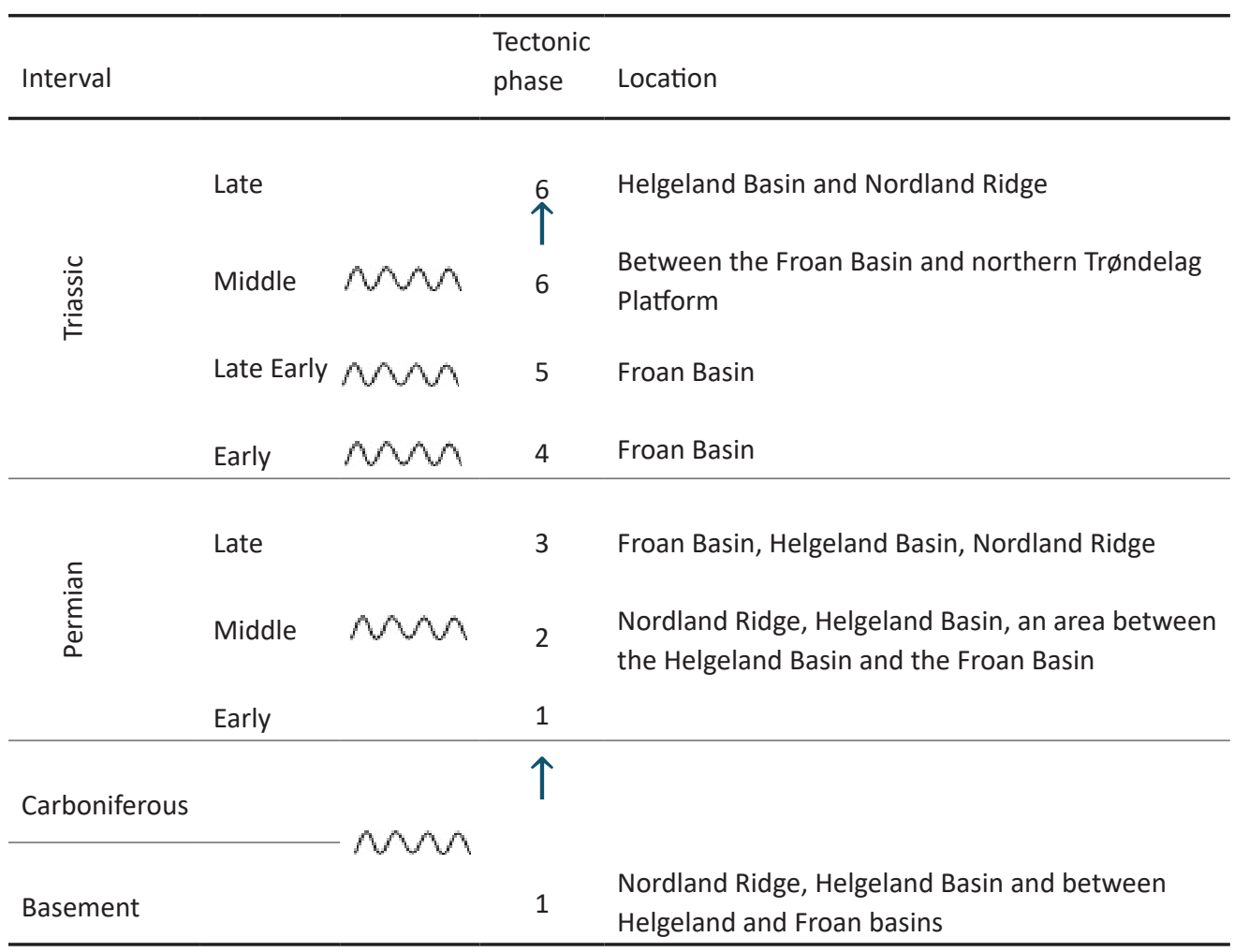




\section{Conclusions}

Seismic surveys (2D and 3D) have been used to investigate the Upper Devonian-Triassic sedimentary fill geometries and tectonic development in the Trøndelag Platform and its subsidiary elements, the Nordland Ridge and Froan and Helgeland basins. Based on seismic interpretation, six major sedimentary fill geometries have been identified. These are (A) wedge-shaped deposits containing fault-ward thickening internal strata, (B) wedge-shaped deposits containing strata of uniform thickness, (C) sedimentary wedges that thicken towards the bounding faults, overlain by gently dipping to more or less flatlying strata, (D) gently dipping strata that thicken towards the deeper basinal areas and onlap onto preexisting topography, (E) sedimentary packages filling depressions, and (F) sedimentary wedges that are bounded by flatter faults, and contain rotated internal strata and a folded top. Onlap and angular unconformities characterise part of the Palaeozoic-Triassic basin fill offshore Mid Norway. Five PalaeozoicTriassic unconformities have been identified in the study area based on the onlap and toplap features of seismic reflectors. These unconformities are a basement unconformity, a mid Permian unconformity, two Early Triassic unconformities and a Middle Triassic unconformity. These sedimentary fill geometries and unconformities have allowed identification of six rifting episodes that have controlled the PalaeozoicTriassic sedimentation in the Trøndelag Platform. These rifts are Devonian-Permian, late Permian, two Early Triassic and Mid-Late Triassic rifting events. One of the Early Triassic and the Mid-Late Triassic rift episodes could not be identified everywhere in the Trøndelag Platform, indicating the occurrence of localised rifting events during the basin development. This work has also allowed the identification of two possible Carboniferous-Permian, isolated, carbonate build-ups in the Helgeland Basin, but more work needs to be done to confirm and improve our understanding of the existence and distribution of Carboniferous-Permian carbonate deposition in the study area.

Acknowledgements. This work was funded by EnPe-Norad under the ANTHEI (Angola Tanzania Higher Education Initiative) scholarship scheme. Equinor provided geophysical data and working facilities to accomplish the project. MNR lines are reproduced by courtesy of SpectrumGeo and TGS. The 3D surveys were reproduced with permission from PGS. Discussions with Halvor Bunkholt and Koen van den Bril are highly appreciated and led to improvement of the work. Jan Einar Ringås and Valentin Zuchuat are thanked for their constructive reviews.

\section{References}

Andrews, S. D. \& Decou, A. 2019: The Triassic of Traill $\varnothing$ and Geographical Society $\varnothing$, East Greenland: Implications for North Atlantic palaeogeography. Geological Journal 54, 2124-2144. https://doi.org/10.1002/gj.3287.

Blystad, P., Brekke, H., Færseth, R.B., Larsen, B.T., Skogseid, J. \& Tørudbakken, B. 1995: Structural elements of the Norwegian Continental Shelf Part II: The Norwegian Sea Region. Norwegian Petroleum Directorate Bulletin 8.

Brekke, H. 2000: The tectonic evolution of the Norwegian Sea Continental Margin with emphasis on the Vøring and Møre basins. In A. Nøttvedt (ed.): Dynamics of the Norwegian Margin, Geological Society, London, Special Publication 167, pp. 327-378. https://doi.org/10.1144/GSL.SP.2000.167.01.13. 
Brekke, H., Sjulstad, H. I., Magnus, C., \& Williams, W. R. 2001: Sedimentary environments offshore Norway - an overview. In O. J. Martinsen \& T. Dreyer (eds.): Sedimentary Environments Offshore Norway-Palaeozoic to Recent, Norwegian Petroleum Society Special Publication 10, pp. 7-37. https://doi.org/10.1016/S0928-8937(01)80006-0.

Bugge, T., Ringås, J. E., Leith, D. A., Mangerud, G., Weiss, H. M., \& Leith, T. L. 2002: Upper Permian as a new play model on the mid-Norwegian continental shelf: Investigated by shallow stratigraphic drilling. American Association of Petroleum Geologists Bulletin 86, 107-127.

https://doi.org/10.1306/61EEDA4E-173E-11D7-8645000102C1865D.

Burgess, P. M., Winefield, P., Minzoni, M., \& Elders, C. 2013: Methods for identification of isolated carbonate buildups from seismic reflection data. American Association of Petroleum Geologists Bulletin 97, 1071-1098. https://doi.org/10.1306/12051212011.

Christiansen, F. G., Piasecki, S., Stemmerik, L., \& Telnæs, N. 1993: Depositional Environment and Organic Geochemistry of the Upper Permian Ravnefjeld Formation Source Rock in East Greenland. American Association of Petroleum Geologists Bulletin 77, 1519-1537. https://doi.org/10.1306/BDFF8EDE-1718-11D7-8645000102C1865D.

Dalland, A., Worsley, D., \& Ofstad, K. 1988: A lithostratigraphic scheme for the Mesozoic and Cenozoic succession offshore mid- and northern Norway. Norwegian Petroleum Directorate Bulletin 4, 65.

Doré, A. G. 1992: Synoptic palaeogeography of the Northeast Atlantic Seaway: late Permian to Cretaceous. In J. Parnell (ed.): Basins on the Atlantic Seaboard: Petroleum Geology, Sedimentology and Basin Evolution, Geological Society, London, Special Publication 62, pp. 421-446. https://doi.org/10.1144/GSL.SP.1992.062.01.31.

Elliott, G. M., Jackson, C. A.-L., Gawthorpe, R. L., Wilson, P., Sharp, I. R., \& Michelsen, L. 2017: Late syn-rift evolution of the Vingleia Fault Complex, HaltenTerrace, offshore Mid-Norway; a test of rift basin tectono-stratigraphic models. Basin Research 29, 465-487. https://doi.org/10.1111/bre.12158.

Elvebakk, G., Hunt, D. W., \& Stemmerik, L. 2002: From isolated buildups to buildup mosaics: 3D seismic sheds new light on upper Carboniferous-Permian fault controlled carbonate buildups, Norwegian Barents Sea. Sedimentary Geology 152, 7-17. https://doi.org/10.1016/S0037-0738(02)00232-4.

Gani, M. R. 2017: Mismatch between time surface and stratal surface in stratigraphy. Journal of Sedimentary Research, 87, 1226-1234. https://doi.org/10.2110/jsr.2017.67.

Guarnieri, P., Brethes, A., \& Rasmussen, T. M. 2017: Geometry and kinematics of the Triassic rift basins in Jameson Land (East Greenland). Tectonics 36, 602-614. https://doi.org/10.1002/2016TC004419.

Gudlaugsson, S. T., Faleide, J. I., Johansen, S. E., \& Breivik, A. J. 1998: Late Palaeozoic structural development of the South-western Barents Sea. Marine and Petroleum Geology 15, 73-102. https://doi.org/10.1016/S0264-8172(97)00048-2.

Hansen, D. M., Redfern, J., Federici, F., Di-Biase, D., \& Bertozzi, G. 2007: Miocene igneous activity in the Northern Subbasin, offshore Senegal, NW Africa. Marine and Petroleum Geology 25, 1-15. https://doi.org/10.1016/j.marpetgeo.2007.04.007. 
Holbrook, J. M., \& Bhattacharya, J. P. 2012: Reappraisal of the sequence boundary in time and space: case and considerations for an SU (subaerial unconformity) that is not a sediment bypass surface, a time barrier, or an unconformity. Earth-Science Reviews 113, 271-302.

https://doi.org/10.1016/j.earscirev.2012.03.006.

Jacobsen, V. W., \& van Veen, P. 1984: The Triassic offshore Norway north of $62^{\circ} \mathrm{N}$. In Spencer, A. M. (ed.): Petroleum geology of the north European margin, Springer, Dordrecht, pp. 317-327. https://doi.org/10.1007/978-94-009-5626-1_23.

Kreiner-Møller, M., \& Stemmerik, L. 2001: Upper Permian lowstand fans of the Bredehom Member, Schuchert Dal Formation, East Greenland. In O. J. Martinsen \& T. Dreyer (eds.): Sedimentary Environments Offshore Norway - Palaeozoic to Recent, Norwegian Petroleum Society Special Publication 10, pp. 51-65. https://doi.org/10.1016/S0928-8937(01)80008-4.

Kyrkjeb $\varnothing$, R., Gabrielsen, R. H., \& Faleide, J. I. 2004: Unconformities related to the Jurassic-Cretaceous synrift-post-rift transition of the northern North Sea. Journal of the Geological Society 161, 1-17. https://doi.org/10.1144/0016-764903-051.

Mitchum Jr, R. M., Vail, P. R., \& Thompson lii, S. 1977: Seismic stratigraphy and global changes of sea level: Part 2. The depositional sequence as a basic unit for stratigraphic analysis: Section 2. Application of seismic reflection configuration to stratigraphic interpretation. American Association of Petroleum Geologists Memoir 26, Seismic Stratigraphy - Applications to Hydrocarbon Exploration, pp. 53-62.

Müller, R., Nystuen, J. P., \& Lie, H. 2005: Late Permian to Triassic basin infill history and palaeogeography of the Mid-Norwegian shelf-East Greenland Region. In Wandås, B.T.G., Nystuen, J.P., Eide, E. \& Gradstein, F. (eds.): Onshore-Offshore Relationships on the North Atlantic Margin, Norwegian Petroleum Society Special Publications 12, pp. 165-189. https://doi.org/10.1016/S0928-8937(05)80048-7.

NPD. 2003: Wellbore (6507/3-2)/ Exploration.

https://factpages.npd.no/en/wellbore/pageview/exploration/all/2954 (March 26, 2020).

NPD. 2004a: Wellbore (6407/10-3)/ Exploration.

https://factpages.npd.no/en/wellbore/pageview/exploration/all/1927 (March 26, 2020).

NPD. 2004b: Wellbore (6507/12-2)/ Exploration.

http://factpages.npd.no/FactPages/Default.aspx?nav1=wellbore\&nav2=PageView|Exploration | All\&nav3=437\&culture=en (March 11, 2018).

NPD. 2013: Wellbore (6507/6-4 A)/ Exploration.

http://factpages.npd.no/FactPages/Default.aspx?nav1=wellbore\&nav2=PageView|Exploration | All\&nav3=6753\&culture=en (January 19, 2018).

Nøttvedt, A., Gabrielsen, R.H. \& Steel, R.J. 1995: Tectonostratigraphy and sedimentary architecture of rift basins, with reference to the northern North Sea. Marine and Petroleum Geology 12, 881-901.

https://doi.org/10.1016/0264-8172(95)98853-W.

Oftedal, B. T., Andresen, A., \& Müller, R. 2005: Early Triassic syn-rift sedimentation at Hold with Hope, Northeast Greenland. In Wandås, B.T.G., Nystuen, J.P., Eide, E. \& Gradstein, F. (eds.): Onshore-Offshore Relationships on the North Atlantic Margin, Norwegian Petroleum Society Special Publications 12, pp. 191-206. https://doi.org/10.1016/S0928-8937(05)80049-9. 
Osmundsen, P.T., Braathen, A., Sommaruga, A., Skilbrei, J.R., Nordgulen, $\varnothing$., Roberts, D., Andersen, T.B., Olesen, O. \& Mosar, J. 2005: Metamorphic core complexes and gneiss-cored culminations along the Mid-Norwegian margin. In B. T. G. Wandås, J. P. Nystuen, E. Eide \& F. Gradstein (eds.): Onshore-Offshore Relationships on the North Atlantic Margin, Norwegian Petroleum Society Special Publications 12, pp. 29-41. https://doi.org/10.1016/S0928-8937(05)80042-6.

Osmundsen, P.T., Eide, E.A., Haabesland, N.E., Roberts, D., Andersen, T.B., Kendrick, M., Bingen, B., Braathen, A., \& Redfield, T. F. 2006: Kinematics of the Høybakken detachment zone and the MøreTrøndelag Fault Complex, central Norway. Journal of the Geological Society 163, 303-318.

https://doi.org/10.1144/0016-764904-129.

Prestvik, T., Torske, T., Sundvoll, B., \& Karlsson, H. 1999: Petrology of early Tertiary nephelinites off mid-Norway. Additional evidence for an enriched endmember of the ancestral Iceland plume. Lithos 46, 317-330. https://doi.org/10.1016/S0024-4937(98)00088-7.

Prosser, S. 1993: Rift-related linked depositional systems and their seismic expression. In G. D. Williams \& A. Dobb (eds.): Tectonics and Seismic Sequence Stratigraphy, Geological Society, London, Special Publication 71, pp. 35-66. https://doi.org/10.1144/GSL.SP.1993.071.01.03.

Ravnås, R., \& Bondevik, K. 1997: Architecture and controls on Bathonian-Kimmeridgian shallow-marine synrift wedges of the Oseberg-Brage area, northern North Sea. Basin Research 9, 197-226.

https://doi.org/10.1046/j.1365-2117.1997.00041.x.

Redfern, J., Shannon, P. M., Williams, B. P. J., Tyrrell, S., Leleu, S., Perez, I. F., Baudon, C., Štolfová, K., Hodgetts, D., Van Lanen, X. \& Speksnijder, A. 2010: An integrated study of Permo-Triassic basins along the North Atlantic passive margin: implication for future exploration. Geological Society, London, Petroleum Geology Conference series 7, 921-936. https://doi.org/10.1144/0070921.

Seidler, L. 2000: Incised submarine canyons governing new evidence of Early Triassic rifting in East Greenland. Palaeogeography, Palaeoclimatology, Palaeoecology 161, 267-293. https://doi.org/10.1016/S0031-0182(00)00126-7.

Seidler, L., Steel, R. J., Stemmerik, L., \& Surlyk, F. 2004: North Atlantic marine rifting in the Early Triassic: new evidence from East Greenland. Journal of the Geological Society 161, 583-592.

https://doi.org/10.1144/0016-764903-063.

Steel, R. R. 1998: Architecture of marine rift-basin successions. American Association of Petroleum Geologists Bulletin 82, 110-146.

Stemmerik, L., Christiansen, F. G., Piasecki, S., Jordt, B., Marcussen, C., \& Nøhr-Hansen, N. 1993: Depositional history and petroleum geology of the Carboniferous to Cretaceous sediments in the northern part of East Greenland. In T. O. Vorren, E. Bergsager, $\varnothing . A$. Dahl-Stamnes, E. Holter, B. Johansen, E. Lie and T.B. Lund (eds.): Arctic Geology and Petroleum Potential, Norwegian Petroleum Society Special Publications 2, pp. 67-87. https://doi.org/10.1016/B978-0-444-88943-0.50009-5.

Stemmerik, L., Clausen, O.R., Korstgård, J., Larsen, M., Piasecki, S., Seidler, L., Surlyk, F. \& Therkelsen, J. 1997: Petroleum geological investigations in East Greenland: project 'Resources of the sedimentary basins of North and East Greenland'. Geology of Greenland Survey Bulletin 176, 29-38. https://doi.org/10.34194/ggub.v176.5058. 
Stemmerik, L., Elvebakk, G., \& Worsley, D. 1999: Upper Paleozoic Carbonate reservoirs on the Norwegian and Arctic Shelf: delineation of reservoir models with application to the Loppa High. Petroleum Geoscience 5, 173-187. https://doi.org/10.1144/petgeo.5.2.173.

Surlyk, F. 1990: Timing, style and sedimentary evolution of Late Palaeozoic-Mesozoic extensional basins of East Greenland. In R. F. P. Hardman \& J. Brooks (eds.): Tectonic Events Responsible for Britain's Oil and Gas Reserves, Geological Society, London, Special Publication 55, pp. 107-125. https://doi.org/10.1144/GSL.SP.1990.055.01.05.

Surlyk, F., Piasecki, S., Rolle, F., Stemmerik, L., Thomsen, L., \& Wrang, P. 1984: The Permian Base of East Greenland. In A. M. Spencer (ed.): Petroleum Geology of the North European Margin, Springer, Dordrecht, pp. 303-315. https://doi.org/10.1007/978-94-009-5626-1_22.

Surlyk, F., Hurst, J. M., Piasecki, S., Rolle, F., Scholle, P. A., Stemmerik, L., \& Thomsen, E. 1986: The Permian of the Western Margin of the Greenland Sea-A future Exploration Target. In M. T. Halbouty (ed.): Future Petroleum Provinces of the World, American Association of Petroleum Geologists Memoir 40, pp. 629-659.

Webber, S., Norton, K. P., Little, T. A., Wallace, L. M., \& Ellis, S. 2018: How fast can low-angle normal faults slip? Insights from cosmogenic exposure dating of the active Mai'iu fault, Papua New Guinea. Geology 46, 227-230. https://doi.org/10.1130/G39736.1.

Zhao, F., Wu, S., Sun, Q., Huuse, M., Li, W., \& Wang, Z. 2014: Submarine volcanic mounds in the Pearl River Mouth Basin, northern South China Sea. Marine Geology 355, 162-172.

https://doi.org/10.1016/j.margeo.2014.05.018.

Zhao, Y., Tong, D., Song, Y., Yang, L., \& Huang, C. 2016: Seismic reflection characteristics and evolution of intrusions in the Qiongdongnan Basin: Implications for the rifting of the South China Sea. Journal of Earth Science 27, 642-653. https://doi.org/10.1007/s12583-016-0708-2. 